\title{
Relation Between Canal and Type of Gardens in Yanagawa City
}

\author{
Yoshihiro NAGAMATSU \\ Faculty of Landscape Architecture, Minami Kyusyu University
}

Key Words: 1.garden type 2. canal 3. circuit style garden

\section{INTRODUCTION}

Yanagawa city in Fukuoka prefecture locates in the southeast of Chikugo plane and lies in the area which made up by Chikugo river and Yabe river, and also lies in the low damp ground of the reclaimed land of Ariake Sea. The height of Yanagawa city above the sea level is only 1 to 2 meters at most and they have clay layer (Ariake clay layer) containing high moisture. And the range of the tide in Ariake Sea is 6 meters at least, and all of the river in this area are sensitive to the ebb and flow.

Because of fertile soil, they have been farming for a long time, and now rice field occupies 60 per cent of Yanagawa city.And, irrigation brought them lots of creeks, and the remains of land-readjustment is left in this city, which make Yanagawa city have the look of the peculiar rural landscape.

The canal which runs longitudinally and latitudinally in Yanagawa city were consolidated for the purpose of the defense of the castle by the proprietor, Yoshimasa Tanaka, in Keichou era(1596-1614). Yoshimasa carried out lots of engineering work, and especially consolidated the canals which have been also utilized for boat transport, irrigation and daily life including drinking water. As for gardens in Yanagawa, they made the most of these circumstances and constructed gardens by utilizing the water of canals in ancient clan era. And this garden style is peculiar to Yanagawa clan which is incidental to the military premises. Some gardens in Yanagawa are already investigated and reported ${ }^{11}$. And by adding the further investigation including another gardens, the features of the gardens in Yanagawa will be made more clear. This is the investigation to grasp the relation between the canals and gardens through the measuring of them. In other words, this is the analysis of pond-shape, the way of bringing water, garden-type, planted trees, and so on.

\section{INVESTIGATION AND ANALYSIS}

The eighteen gardens in Yanagawa city were measured and investigated from June in 1983 to September in 1989. As the result of it, each gardens had their own measured drawings and analyzed their peculiarity about the water utilization, the materials of garden-structures, garden-form, pond- 


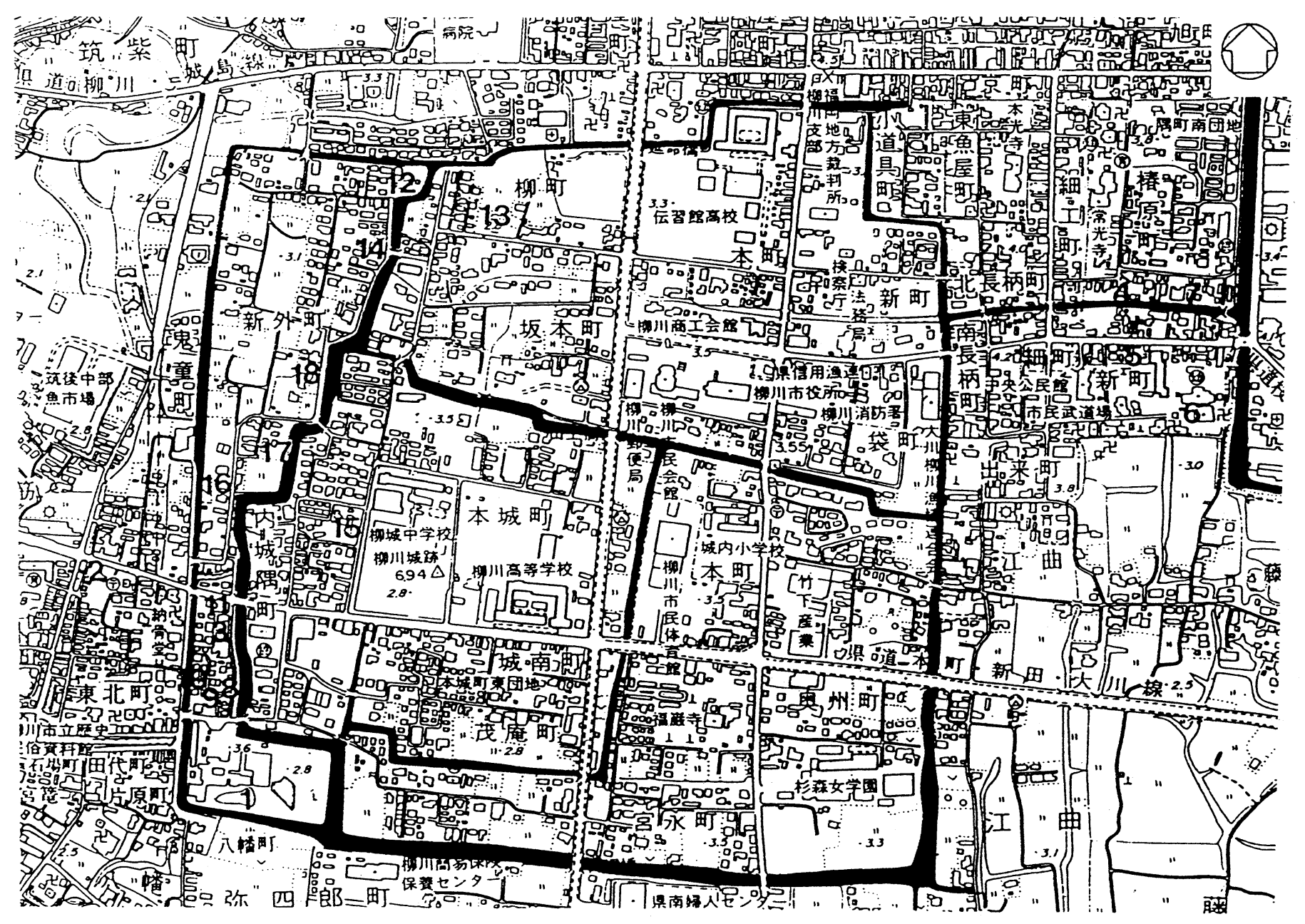

Fig. 1 The canal in Yanagawa city and the location of the gardens
1 Syoutouen
2 Toshima's garden
3 Tomokiyo's garden
4 Isibashi's garden
5 Tomiyasu's garden
6 The garden for Shinsyouji
7 Tsuru's garden
8 Asada's garden
9 Aramaki's garden
10 Sakai's garden
11 The garden for Syoumeiji
12 Takehara's garden
13 Noda's garden
14 The garden for Seijirou Yamazaki 15 Tachibana's garden 16 Aoki's garden
17 Yamazaki's garden

18 Totoki's garden

type, planted trees, and the classification of the garden trees depended on the season. And the features of the gardens are as follows(the drawings show garden-form and the location of structure, pond, and planted trees):

1) Shoutouen (a villa of the Tachibanas')(Shinhokamachi)

In Genroku era (1688-1704), this garden originated in such a circumstance that Akitora, who was the third feudal load, made it as the imitation of the scenery of Matsushima in Sendai for the consolation of his mother's old age. After that, it was extended to the west side and completed in around 23rd in Meiji era (in 1890).

The garden is composed of mainly pond and rocks, and has grove which has only Pinus Thunbergii trees. And the garden is covering a space of $2800 \mathrm{~m}^{2}$, and having the rise and fall of only 1 meter (almost flat) and have no artificial hill. As far as the pond, 1.5 meter in depth, it is rectangle and expanded to the east and the west. It has an area of $1250 \mathrm{~m}^{2}$ and occupy the 50 per cent of the whole garden. The pond gets the water from the outside canal by way of the water path in the north side of the premises, and the water flow into the pond from east side to west side. And the water 


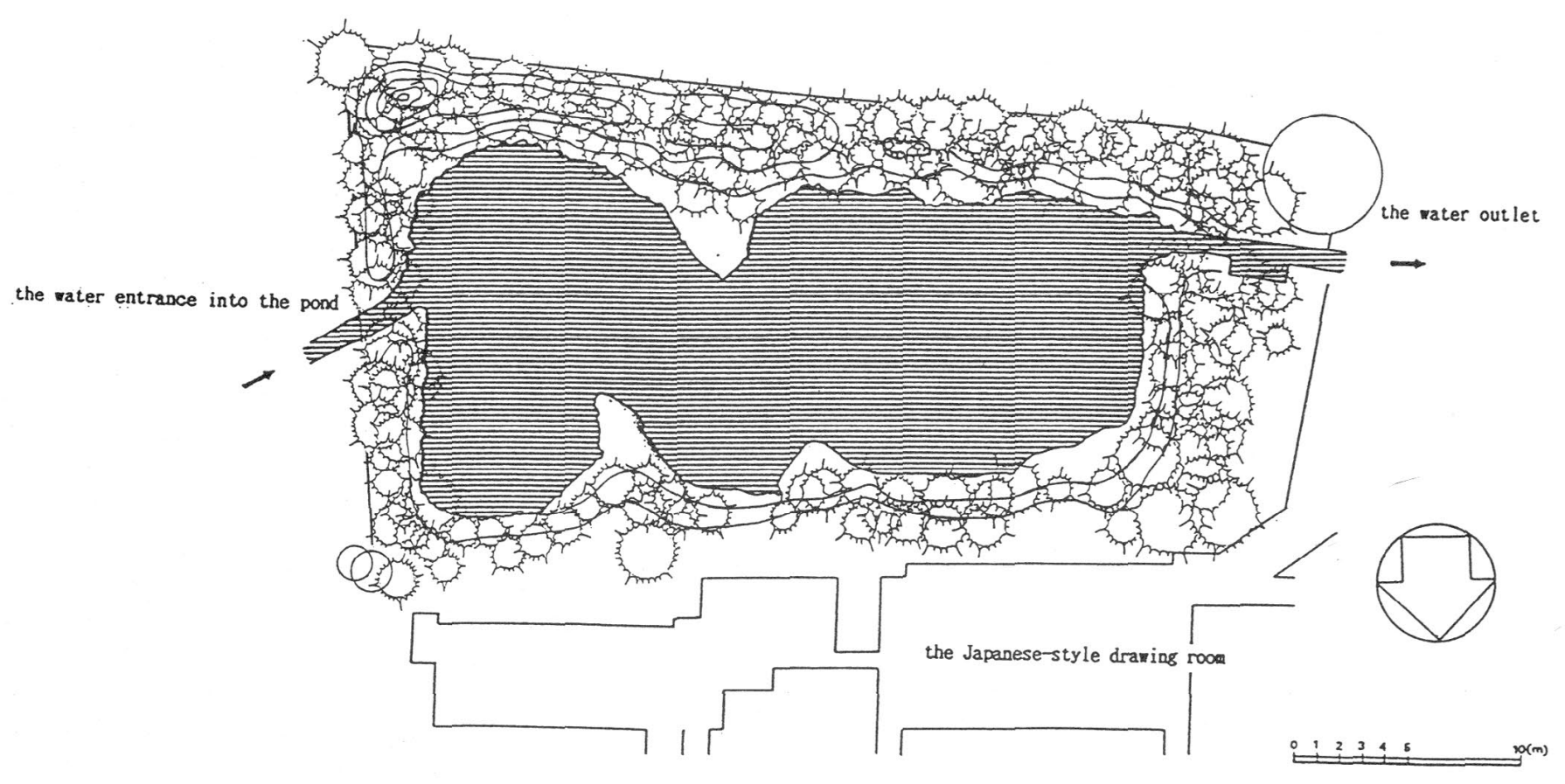

fig.2 Shoutouen

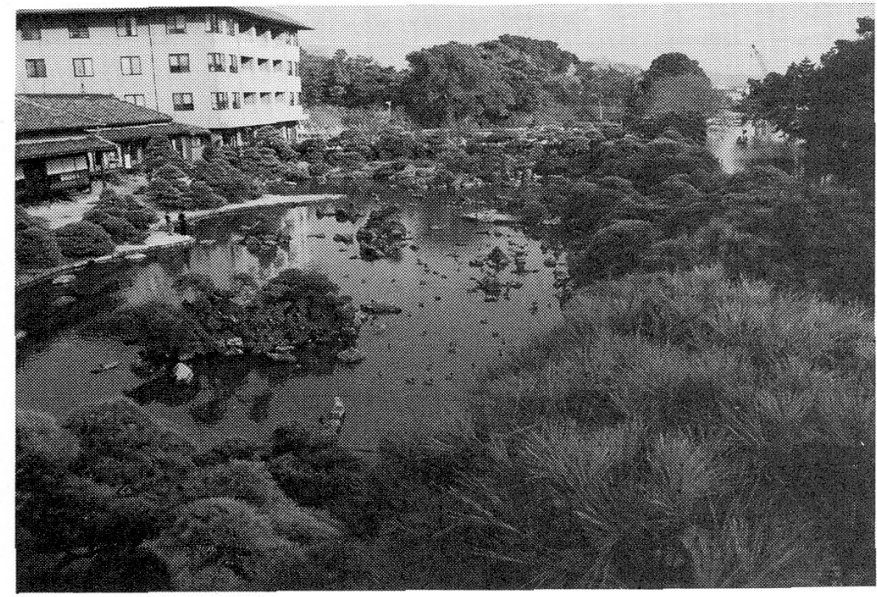

Photo 1 Shoutouen

The pond gets the water from the outside canal by way of the water path in the north side of the premises, and the water flow into the pond from east side to west side.

pass through under the premises and turns to irrigation water(Fig.2). The garden has 280 old Pinus Thunbergii trees, about 1500 stones, 14 stone lanterns, and large kutunugi-isi which is said that it might be the base stone of the ancient castle tower.

2) Toshima's garden (Ondou-machi)

Kanehisa Yoshida, who is the accountant of
Tachibana feudal clan, constructed this garden in Kansei era (1789-1801), which was presented to the feudal load and used as the tea room. This is the one-view-point-style garden having the emphasis on the pond which has a space of $110 \mathrm{~m}^{2}$. And the garden has an area of $1000 \mathrm{~m}^{2}$. The water comes from the left (east) side canal, and in the center of the pond it has the stepping stones to walk across it. In addition to these, this side in the pond, there are round stones which arranged with a gentle slope, which express a suhama.

The pond is finally changed into waterway and flows into the west side (Fig.3). And the emphasis is on the watercourse, which is sensitive to the ebb and flow.

Around the pond it has the trees such as Podocarpus macrophylla, Abies firma, Pinus Thunbergii, Camellia japonica, Acer palmatum, Rhododenron indicum, Cleyera japonica, and Ilex crenata. And tall trees planted behind the garden express high mountain. 


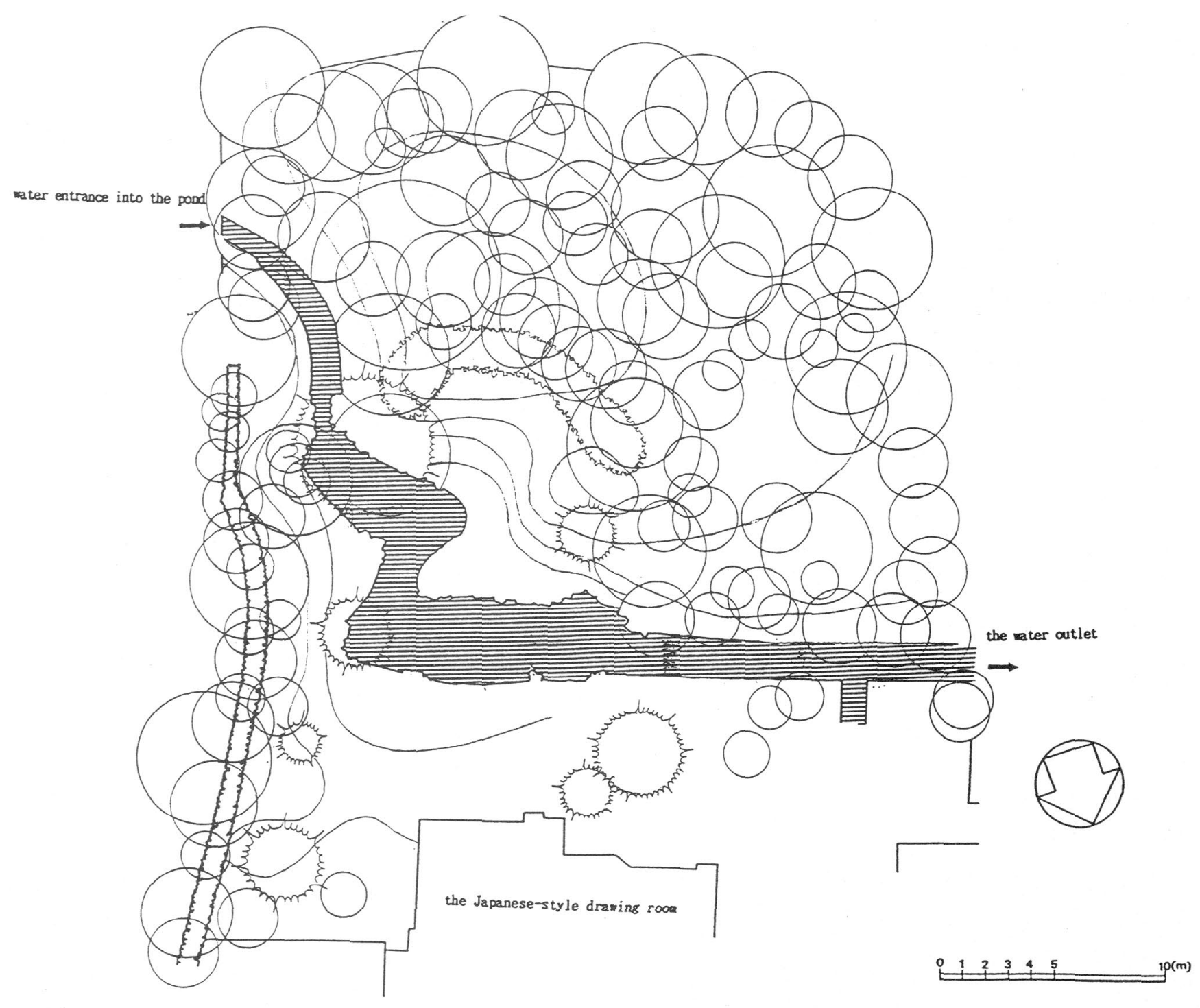

Fig.3 Toshima's garden (measured by Nagamatsu and others)

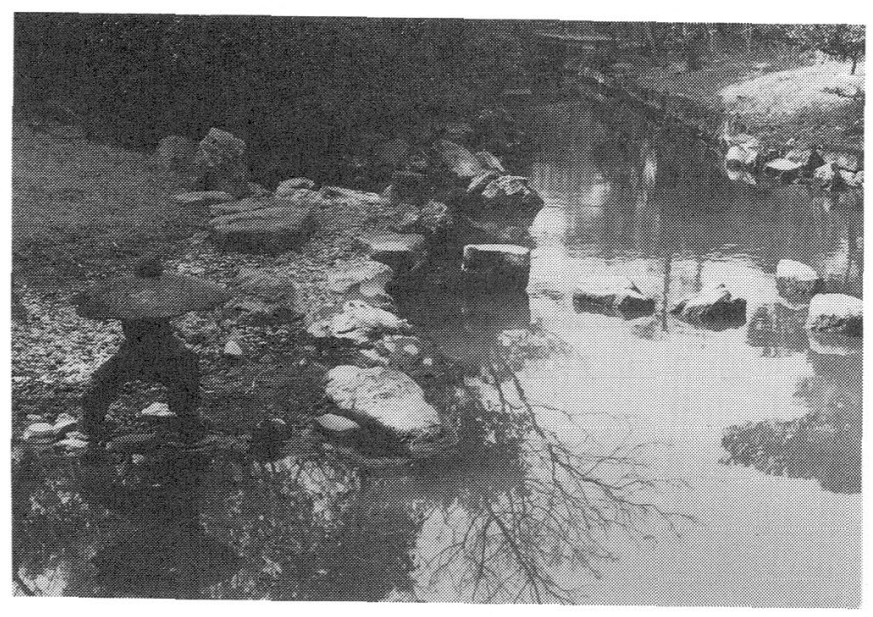

Photo 2 Toshima's garden The pond is finally changed into waterway and flows into the west side.

\section{3) Tomokiyo's garden (Ondou-machi)}

This is the one-view-point-style garden which has the water from the canal running east and west. Similar to the Asada's garden, the watercourse itself is to the east and west, but because of having it with meandering considerably, it has the effect to express a deep garden (Fig.4). It has stakes near the water entrance, and is constructed with threedimensional by large and small stones around the pond in order to express variety. The space of the whole garden is $200.8 \mathrm{~m}^{2}$ and that of the pond, $23 \mathrm{~m}^{2}$. And Quercus glauca, Eurya emarginata, Prunus Mume, Pinus Thunbergii, and etc. are planted in the garden. 


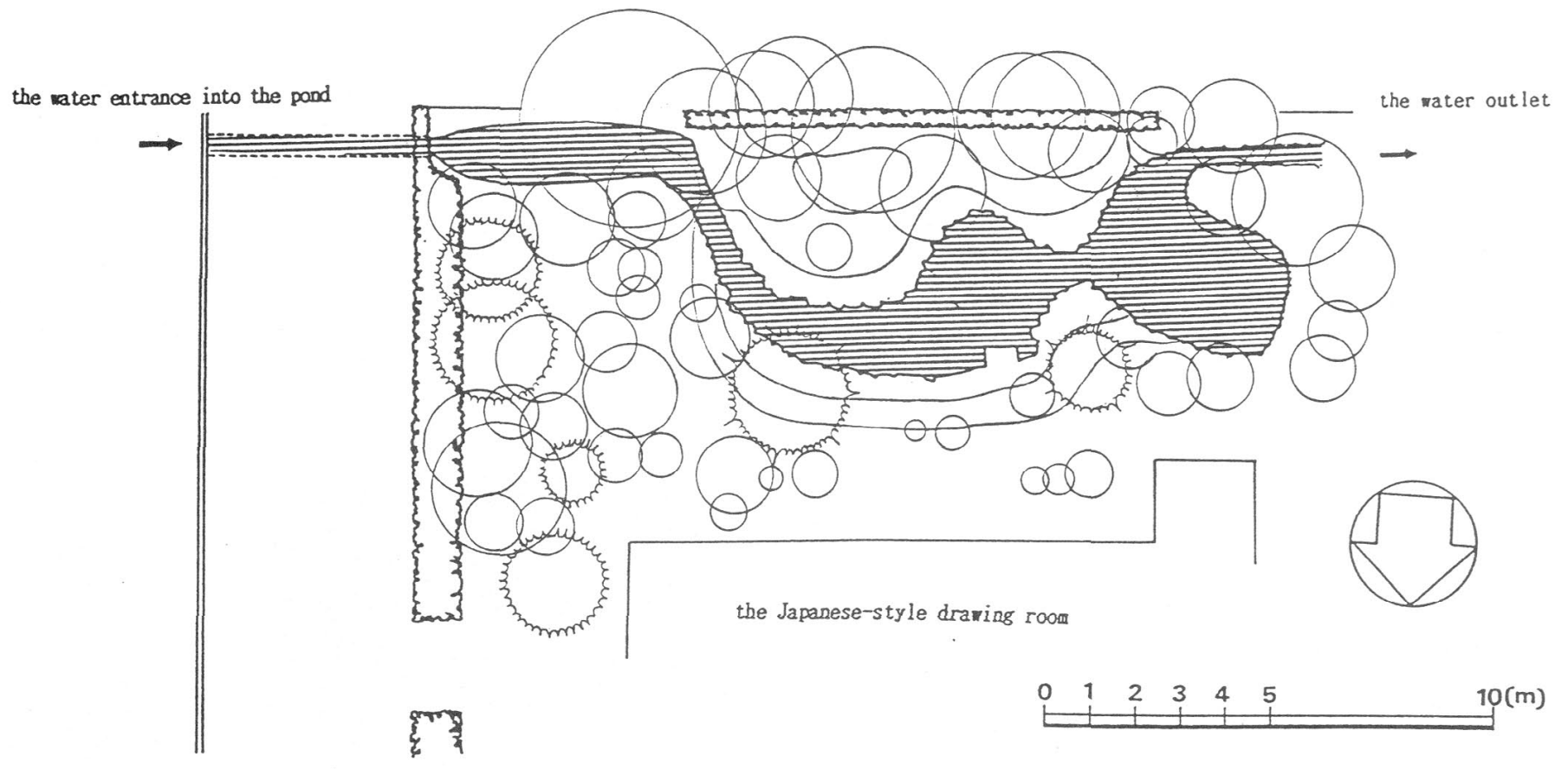

Fig.4 Tomokiyo's garden (measured by Nagamatsu and others)

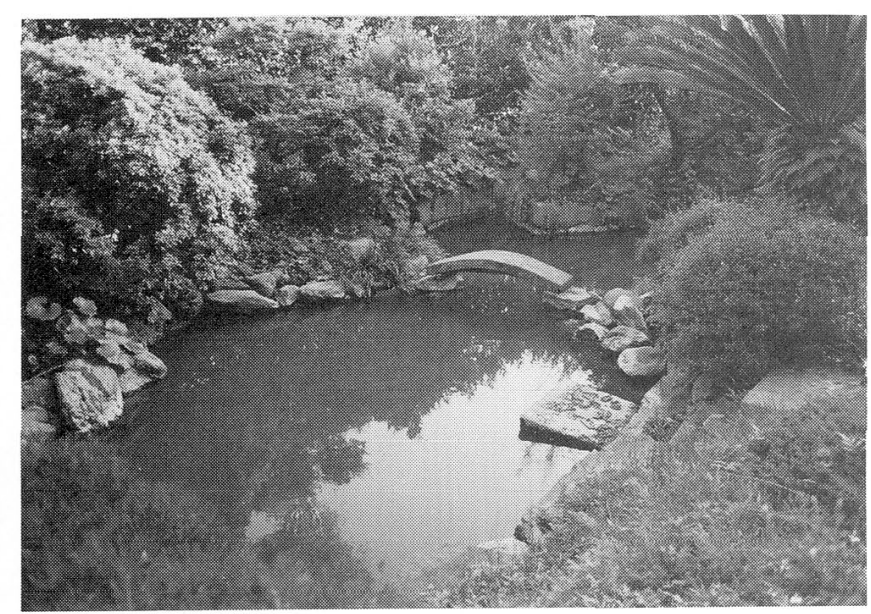

Photo 3 Tomokiyo's garden

Similar to the Asada's garden, the watercourse itself is to the east and west, but because of having it with meandering considerably, it has the effect to express a deep garden.

4) Ishibashi's garden (Tsubahara-machi)

It is the military premises facing its south side to the castle-moat. The width of the moat is about 8 meters. The garden locates on the south side of the waterway (the moat is put between the premises and the garden), which lead to the style of admiring with squat from the drawing room. In the center of the garden, it has the concave on the south of the moat, and the waterway running east and west is utilized as it is (Fig.5) At the left side of the concave the yukimi-style stone lantern is placed as an annex landscape, which has the effect to express crisp landscape and repose. At the backward of the garden, it has an artificial hill, which brings the image of deep garden.

The garden is about $230 \mathrm{~m}^{2}$, and the concave area is about $23 \mathrm{~m}^{2}$. The main plants which make the garden three-dimensional are Podocarpus macrophylla, Hibiscus mutabilis, Pinus densiflora, Acer palmatum, and etc..

A boat is utilized to go in and out of the garden. 5) Tomiyasu's garden (Shin-machi)

Behind the site, the canal runs east and west, which lead to the pond which is looked on as important in this garden. It is the one-view-pointstyle garden and the emphasis is on this pond (Fig.6). The garden is about $400 \mathrm{~m}^{2}$, and the pond, $57 \mathrm{~m}^{2}$, and in the center of the garden it has an artificial hill.

The area around the pond, it has lots of large 


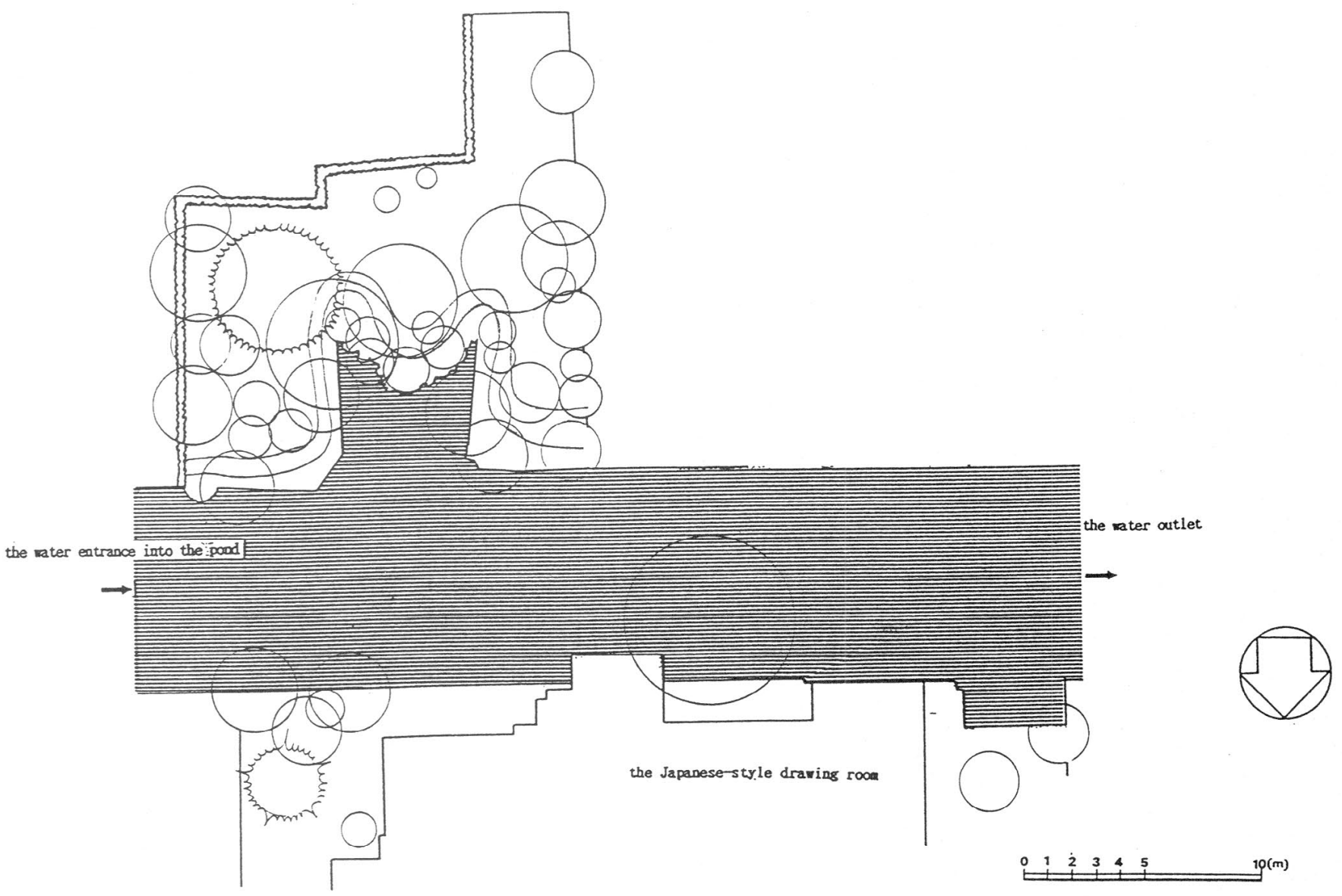

Fig.5 Ishibashi's garden (measured by Nagamatsu and others)

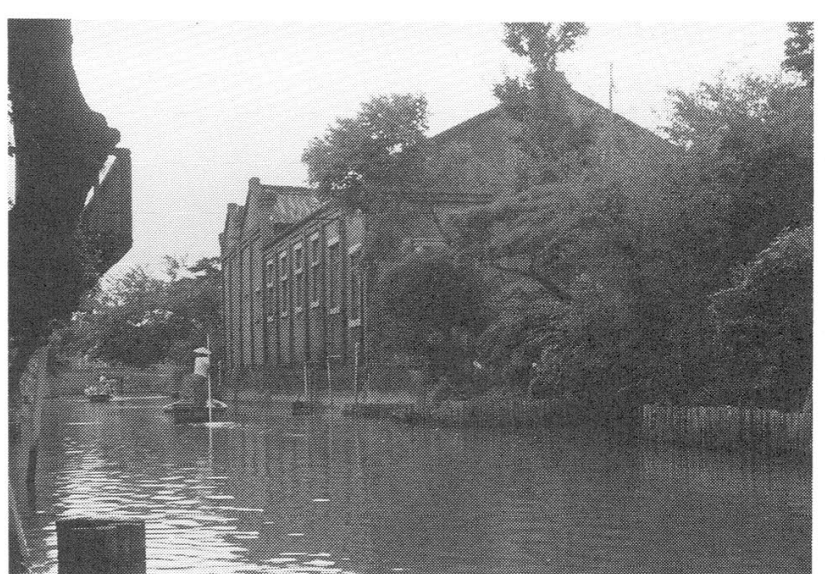

Photo 4 Ishibashi's garden

In the center of the garden, it has the concave on the south of the moat,and the waterway running east and west is utilized as it is.

and small stone-structures, and also has suhama made by being put round stones. The pond has a large head of water, and also has archbridge and stone bridge composed of natural stones, which brings elegance.
The garden has 15 stone lanterns and kutunugi ishi. Tall trees such as Cinnamomum Camphora, Quercus glauca, Chamaecyparisobtusa,Cryptomeria japonica, and Podocarpus macrophylla are planted in the garden, and whole of the garden is covered with deep green, which brings crisp land scape. And the pond mirror these trees.

6) The garden of shinsyouji (Shin-machi)

It is the Buddhist temple of Yoshimasa Tanaka and adjoining to Tomiyasu's garden. This garden, surrounded by the trees grown densely, has the long and narrow water path flowing into the pond in the south side and out to west side (Fig.7).

This is the circuit style garden, but also has a fine view from the drawing room. Around the garden it has stakes, and has the gorgeous taki-ishigumi in the northeast of the garden. In the pond it has nakazima and yukimi-style stone lantern. At the back of the pond, Rhododenron 


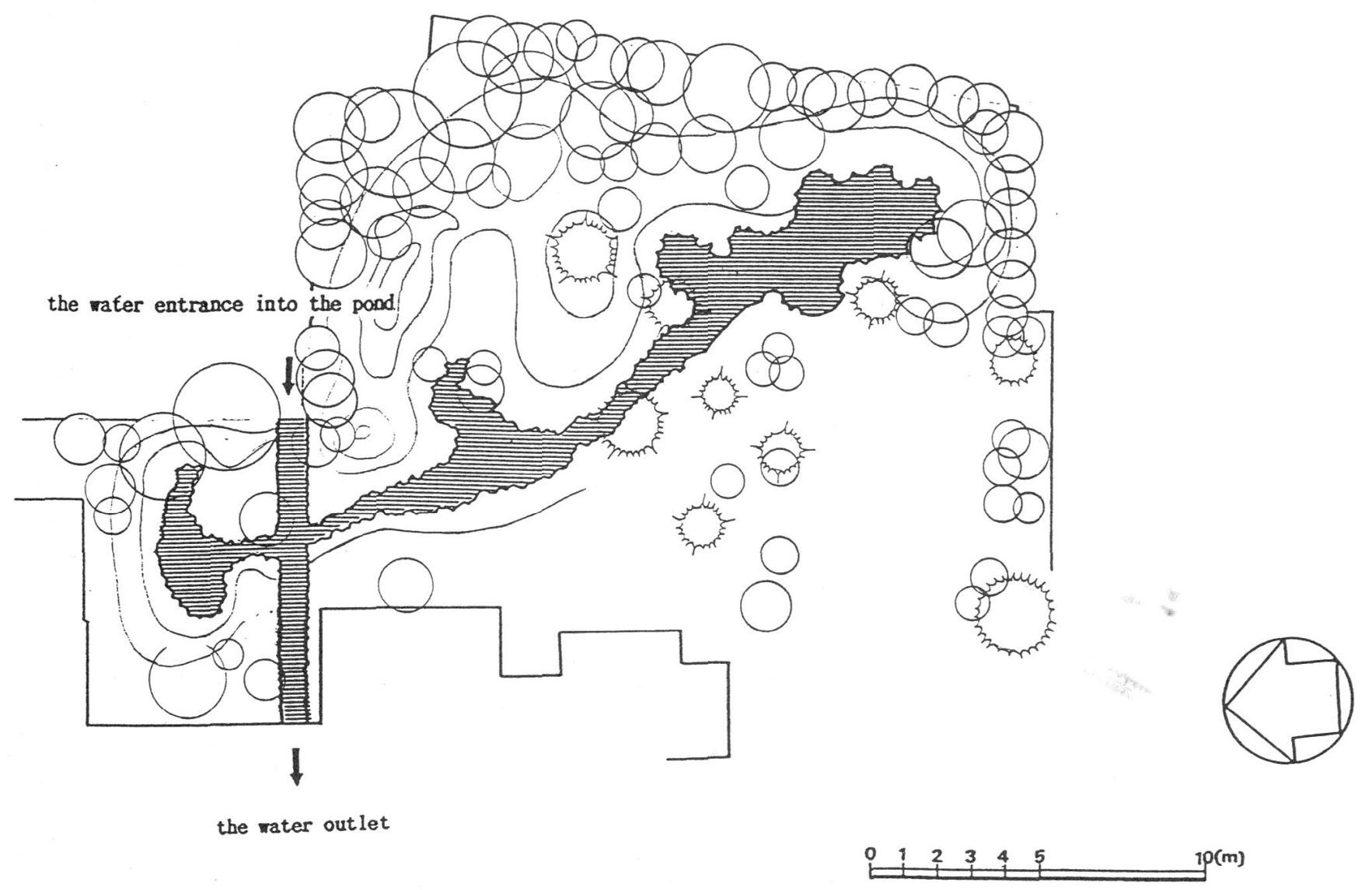

Fig.6 Tomiyama's garden (measured by Nagamatsu and others)

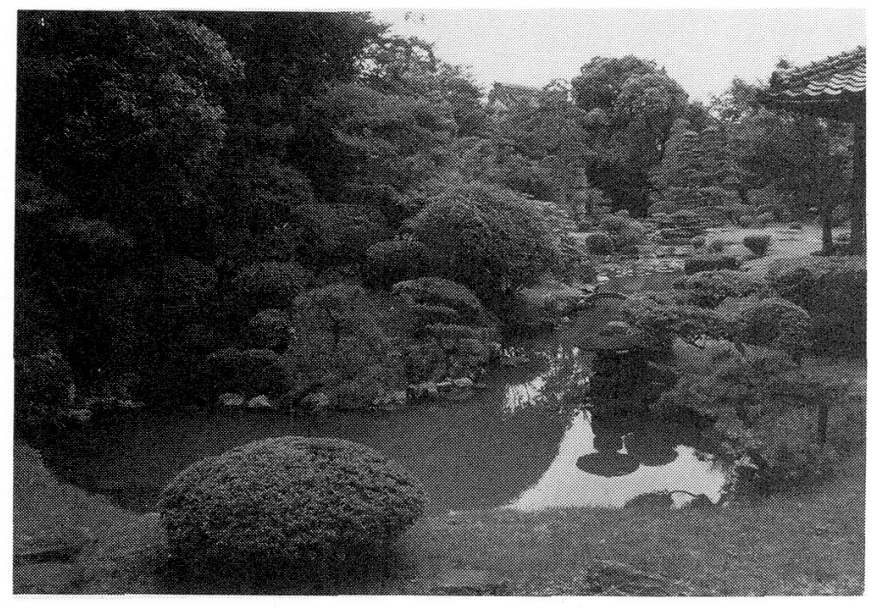

Photo 5 Tomiyama's garden

Behind the site,the canal runs east and west,which lead to the pond which is looked on as important in this garden.

indicum are planted, which symbolize a range of mountains.

In addition to the large trees such as Aphananthe aspera, Podocarpus macrophylla, Quercus glauca, and Metasequoia Glyptostroboides, trees such as
Acer palmatum, Pinus Thunbergii, and Prunus Mume are planted in the garden. The space of the garden and the pond are $1050 \mathrm{~m}^{2}$ and $140 \mathrm{~m}^{2}$ respectively.

7) Tsuru's garden (Tsubahara-machi)

The pond has the water entrance and the outlet at the back of left side and the right side respectively. This is the circuit style garden having the emphasis on the pond. In the water path, large and small stones are arranged, which makes the water flow trickle (Fig.8).

In the pond the stakes are arranged, and round stones are paved at the edge of the water, which shapes a suhama. A giant Euonymus alatus which is planted in front of the garden has the appearance of artificial hill. A rectangle kutunugi-ishi set at the edge of veranda, and it is possible to go down to the garden by use of it and stepping stones. It is the small size garden having the space of $280 \mathrm{~m}^{2}$, 


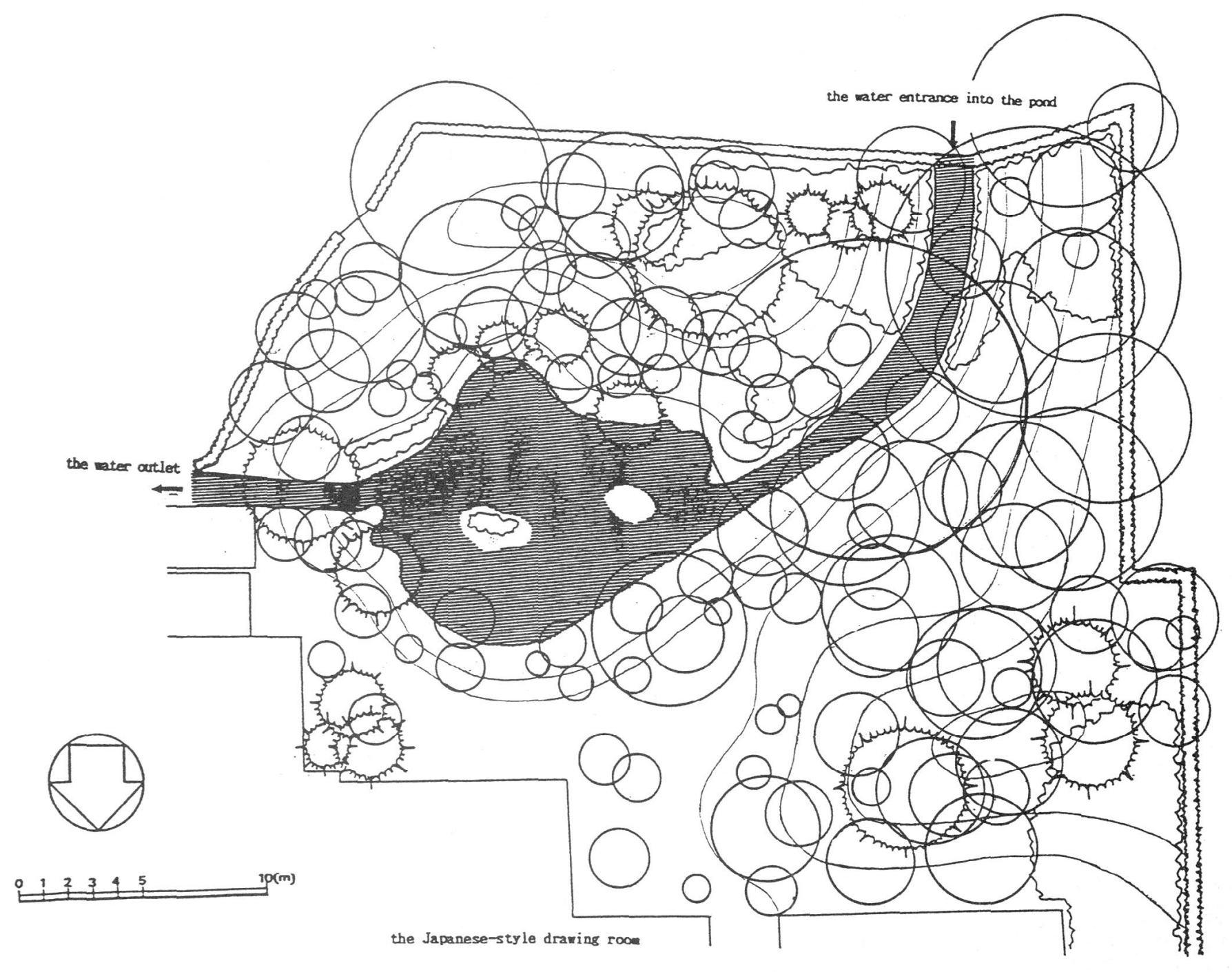

Fig.7 The garden for Shinsyouji (measured by Nagamatsu and others)

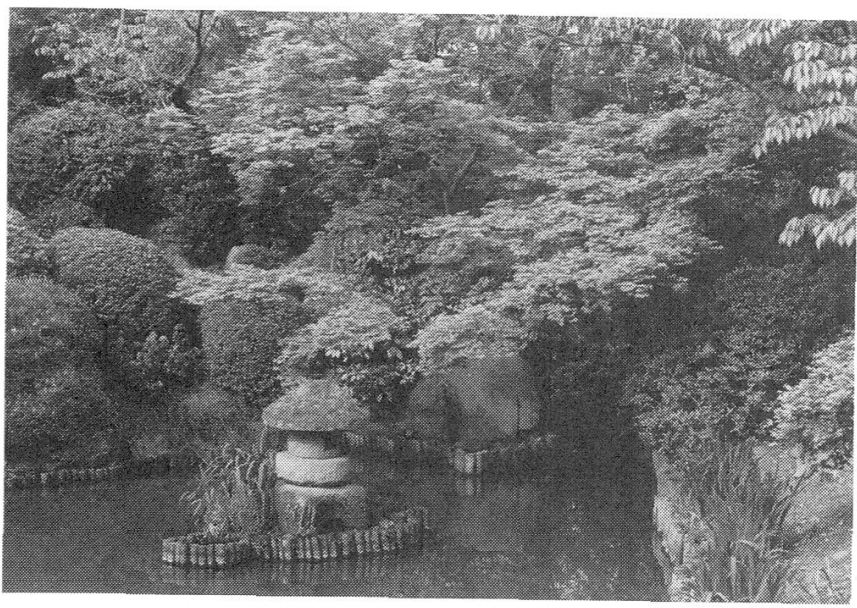

Photo 6 The garden of Shinsyouji

This garden, surrounded by the trees grown densely, has the long and narrow water path flowing into the pond in the south side and out to west side.

and the pond, $36 \mathrm{~m}^{2}$.

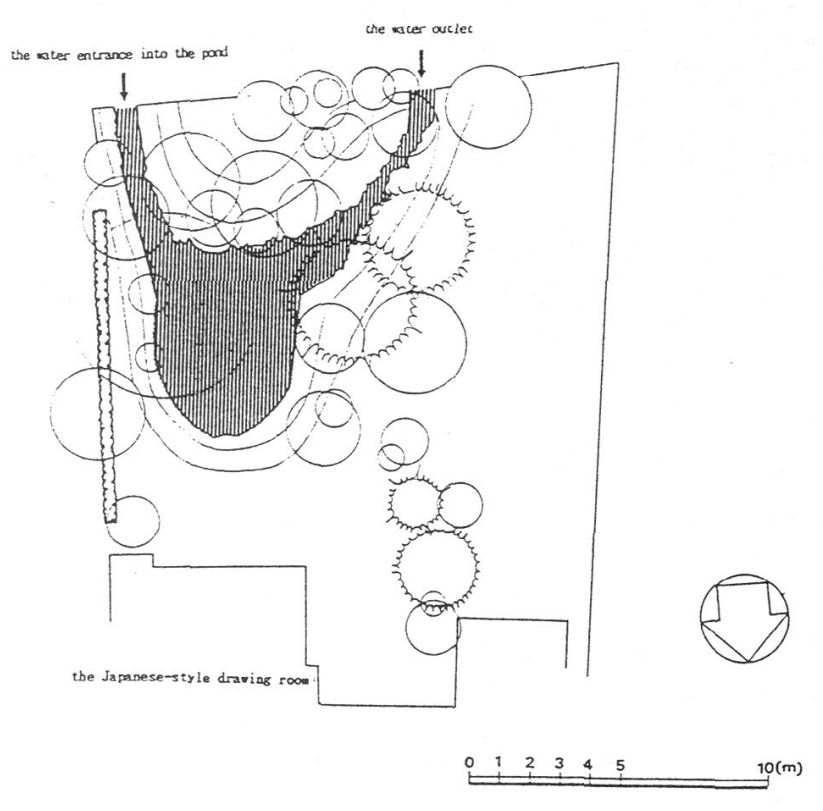

FIg.8 Tsuru's garden (measured by Nagamatsu and others) 


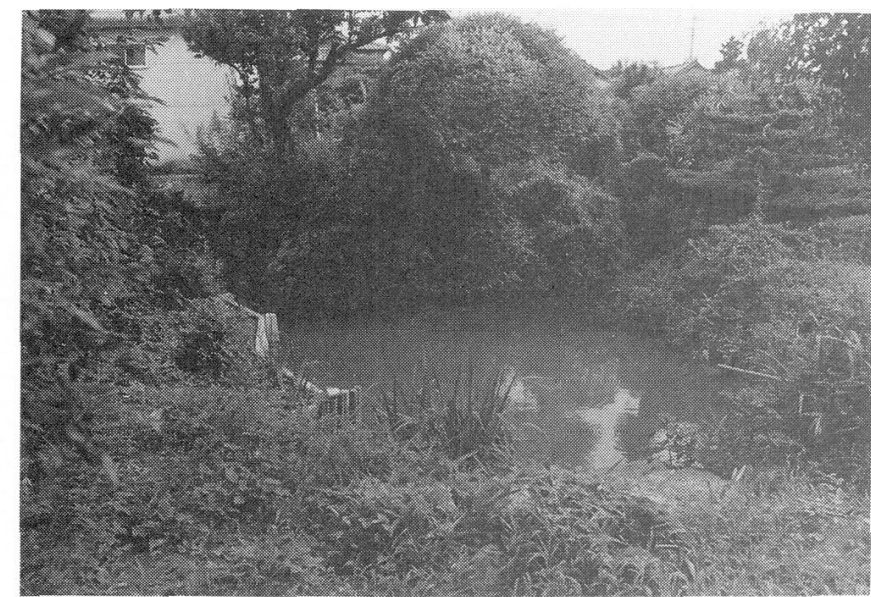

Photo 7 Tsuru's garden

The pond has the water entrance and the outlet at the back of left side and the right side respectively.

\section{8) Asada's garden (Ondou-machi)}

This is the one-view-point-style garden getting water from the canal in the east side. The pond extend from east to west linearly and at the water's edge in this side of the pond, the round stones are paved with slow slope and shapes a suhama (Fig.9). In the water path, large and small stones are constructed and the gate of waterfall is expressed

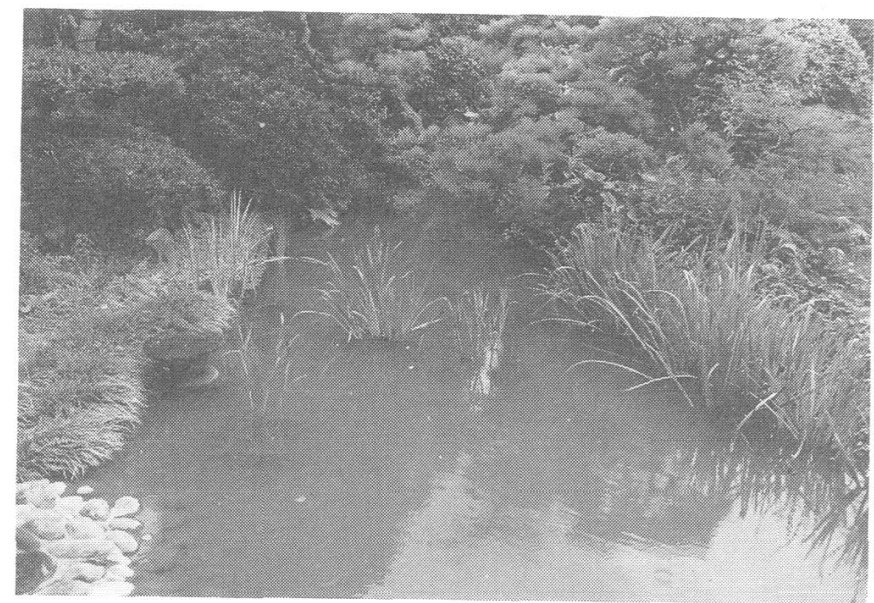

Photo 8 Asada's garden

This is the one-view-point-style garden getting water from the canal in the east side

by the tateishi. This is the small size garden, and the space of it and the pond are about $370 \mathrm{~m}^{2}$ and $40 \mathrm{~m}^{2}$ respectively. The kinds of trees planted in this garden are Lithocarpus edulis, Chamaecyparis obtusa, Ilex rotunda, Pinus Thunbergii, and so on.

9) Aramaki's garden (Ondou-machi)

It has the waterway from the pond in the Asada's garden and into the inside of this site. The pond has

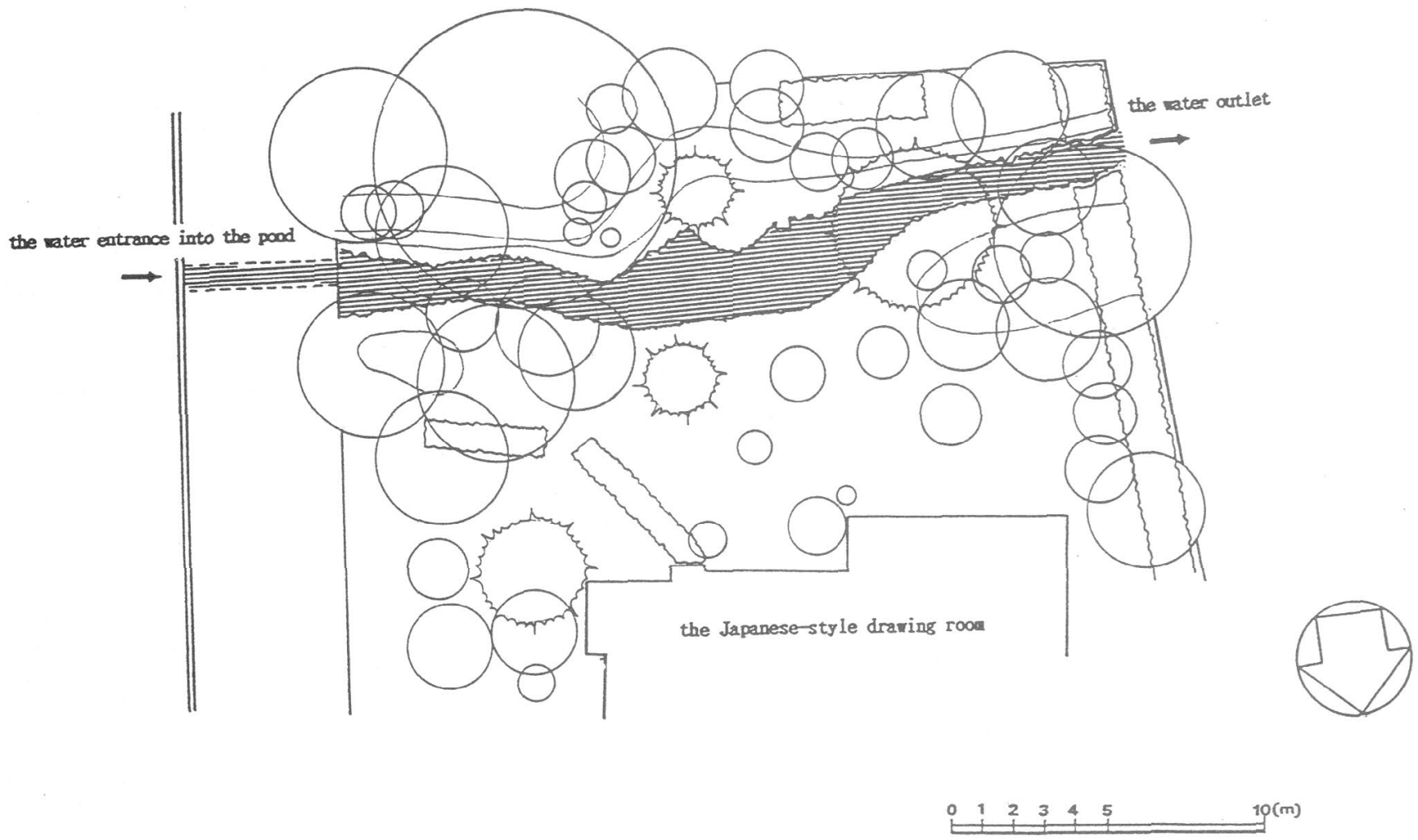

Fig.9 Asada's garden (measured by Nagamatsu and others) 


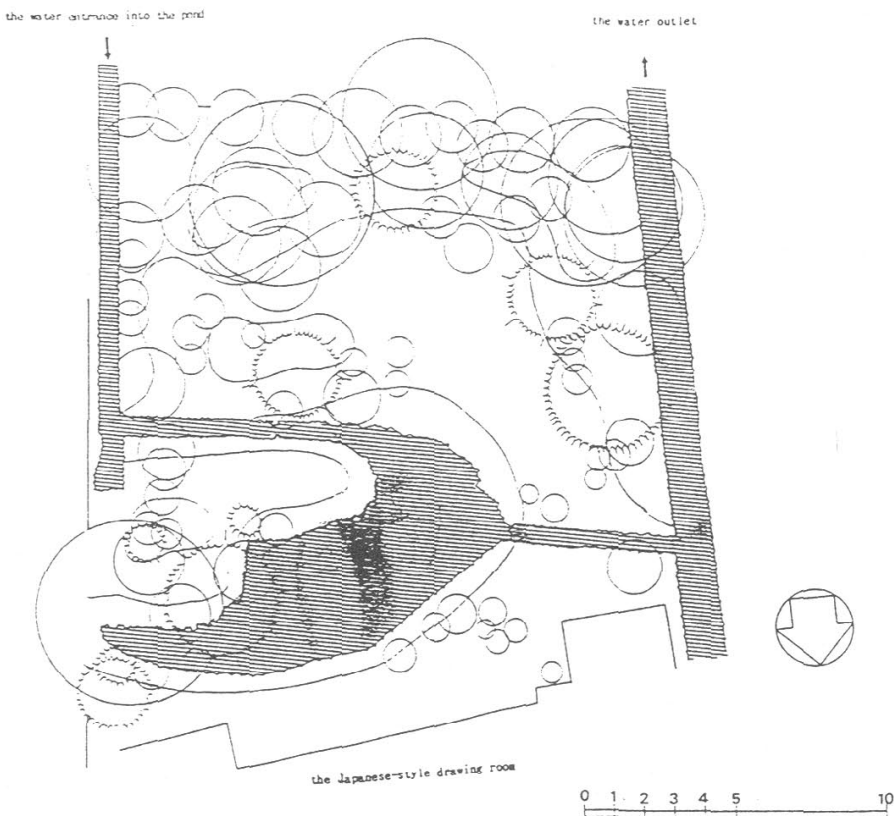

FIg.10 Aramaki'ss garden (measured by Nagamatsu and others)

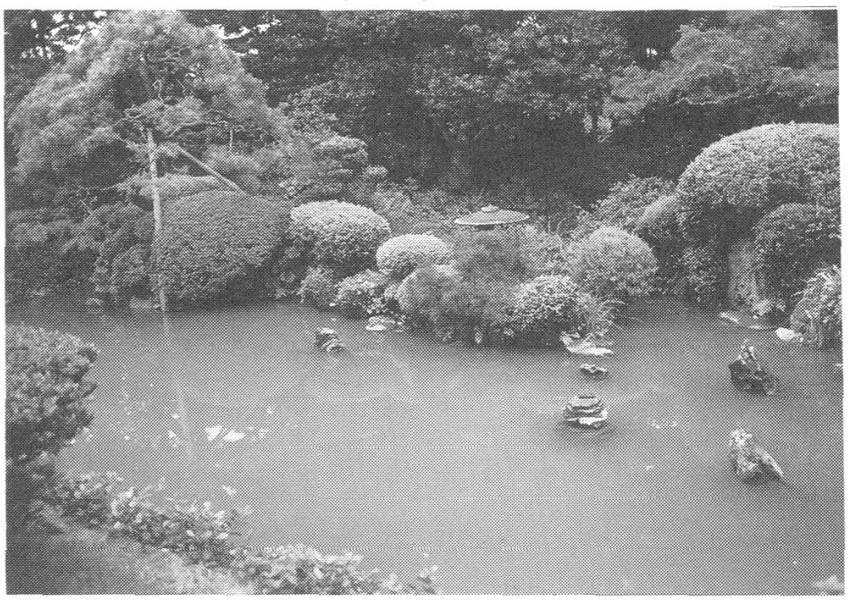

Photo 9 Aramaki's garden

It has the waterway from the pond in the Asada's garden and into the inside of this site.

artificial hill which has an appearance of a high mountain. Around the pond, it has stone-structures composed of natural stones and quarried stones, and a suhama is expressed in the center of the garden. This is the circuit style garden having the pond as the heart of it. And the pond turns into water path and runs into the next door, Sakai's garden (Fig.10). This garden has an area of $350 \mathrm{~m}^{2}$, and the pond, $60 \mathrm{~m}^{2}$. The trees in the garden are mainly Aphananthe aspera, Ilex rotunda, and Podocarpus macrophylla.

10) Sakai's garden (Ondou-machi)
The water path rise in neighboring, Aramaki's garden, and flows into the pond in the center of this garden and still connected to the canal in the south side (Fig.11). This is the pond-appreciation style garden having the emphasis on the pond. In the pond, the artificial hill is constructed. Behind the garden, it has tall trees such as Cinnamomum Camphora, Celtis sinensis, Prunus yedoensis, and Acer palmatum, which gives us magnificence.

In this side of the pond, suhama is constructed by round stones. The takiishi-gumi behind the garden, symbolizing high mountain, has a sturdiness. In the front of the garden, the lawn which is covering ground looks flesh, and the garden itself looks like a deep one. The garden is $720 \mathrm{~m}^{2}$, and the pond, $84 \mathrm{~m}^{2}$.

11) The garden of Syoumeiji (Ondou-machi)

It is the one-view-point-style garden having the water from the canal in the east side of the site(Fig.12). It locates side by side with the Asada's and the Tomokiyo's gardens. The garden is elegance one and has an area of $500 \mathrm{~m}^{2}$, and the pond, $107.4 \mathrm{~m}^{2}$. The garden has such kinds of trees as Pinus Thunbergii, Cycas revoluta, Podocarpus macrophylla, Aphananthe aspera, Ilex rotunda and Quercus glauca. The watercourse

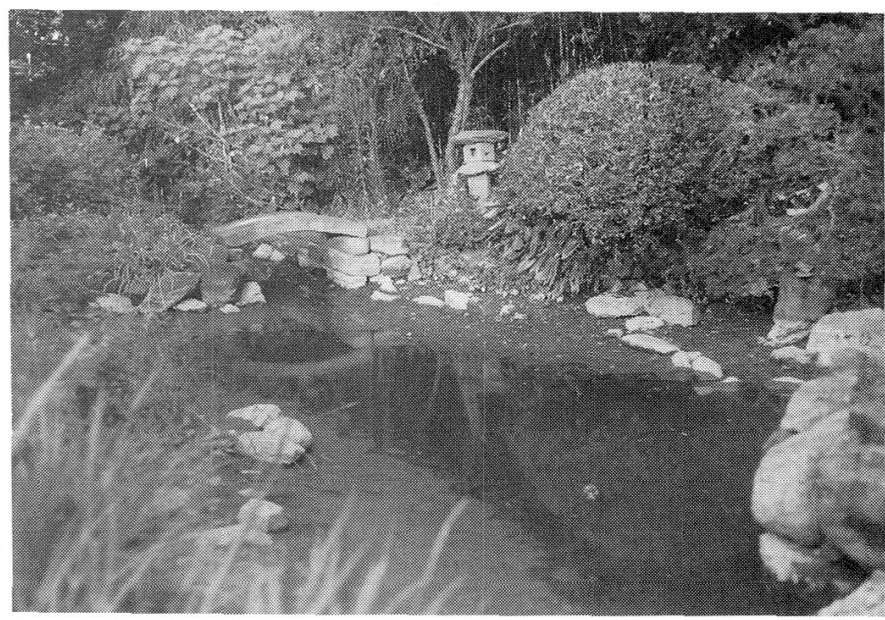

Photo 10 Sakai's garden

The water path rise in neighboring, Aramaki's garden, and flows into the pond in the center of this garden and still connected to the canal in the south side. 


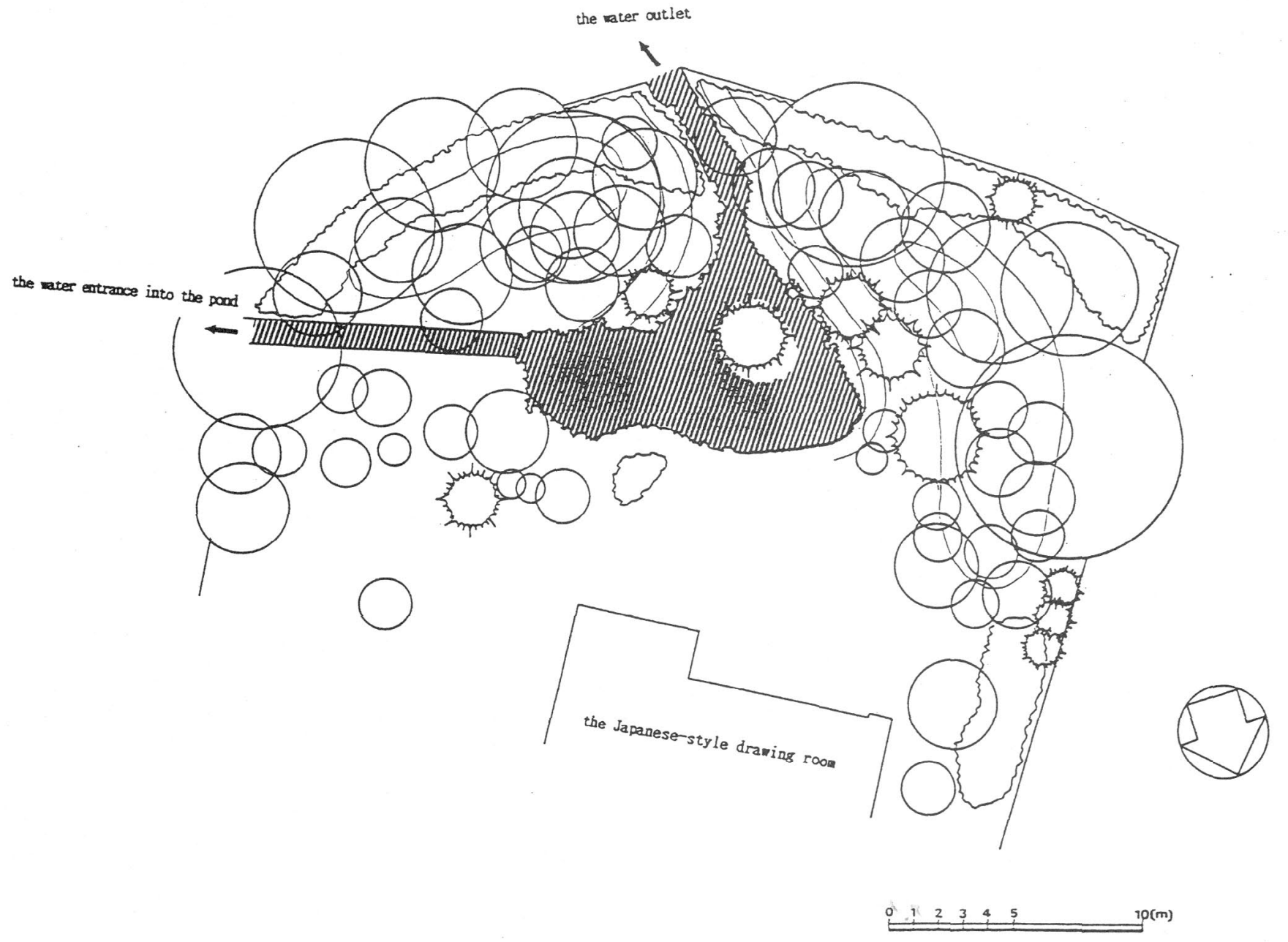

Fig.11 Sakai's garden (measured by Nagamatsu and others)

extend with meanderingly to the east and west, which has the effect to make the whole garden have depth and expanse. Nowadays, around the water entrance of the pond are repaired and constructed natural-like takiishi-gumi, which has the looks of splendor. In the garden, it has three kasuga-style stone lanterns, two yukimi-style stone lanterns, and a five-storied pagoda, which gives the garden feeling.

12) Takehara's garden (Shinhoka-machi)

The garden locates in the south side of the military premises and has the pond with long and slender to the east and west. The canal runs in the south side and the east side in the site, and the water is from the east side canal and to the west side one(Fig.13). Around the water entrance of the

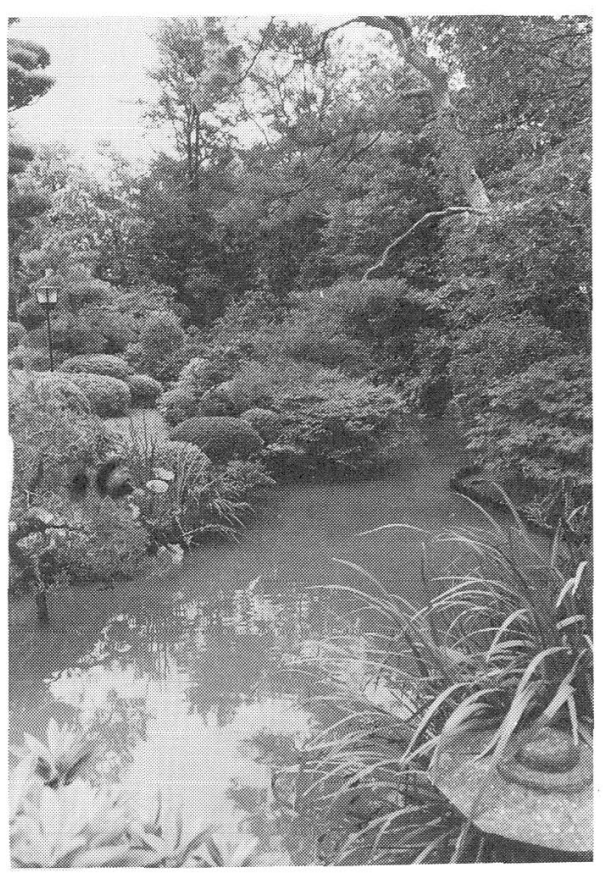

Photo 11 The garden of Syoumeiji

It is the one view point style garden having the water from the canal in the east side of the site. 

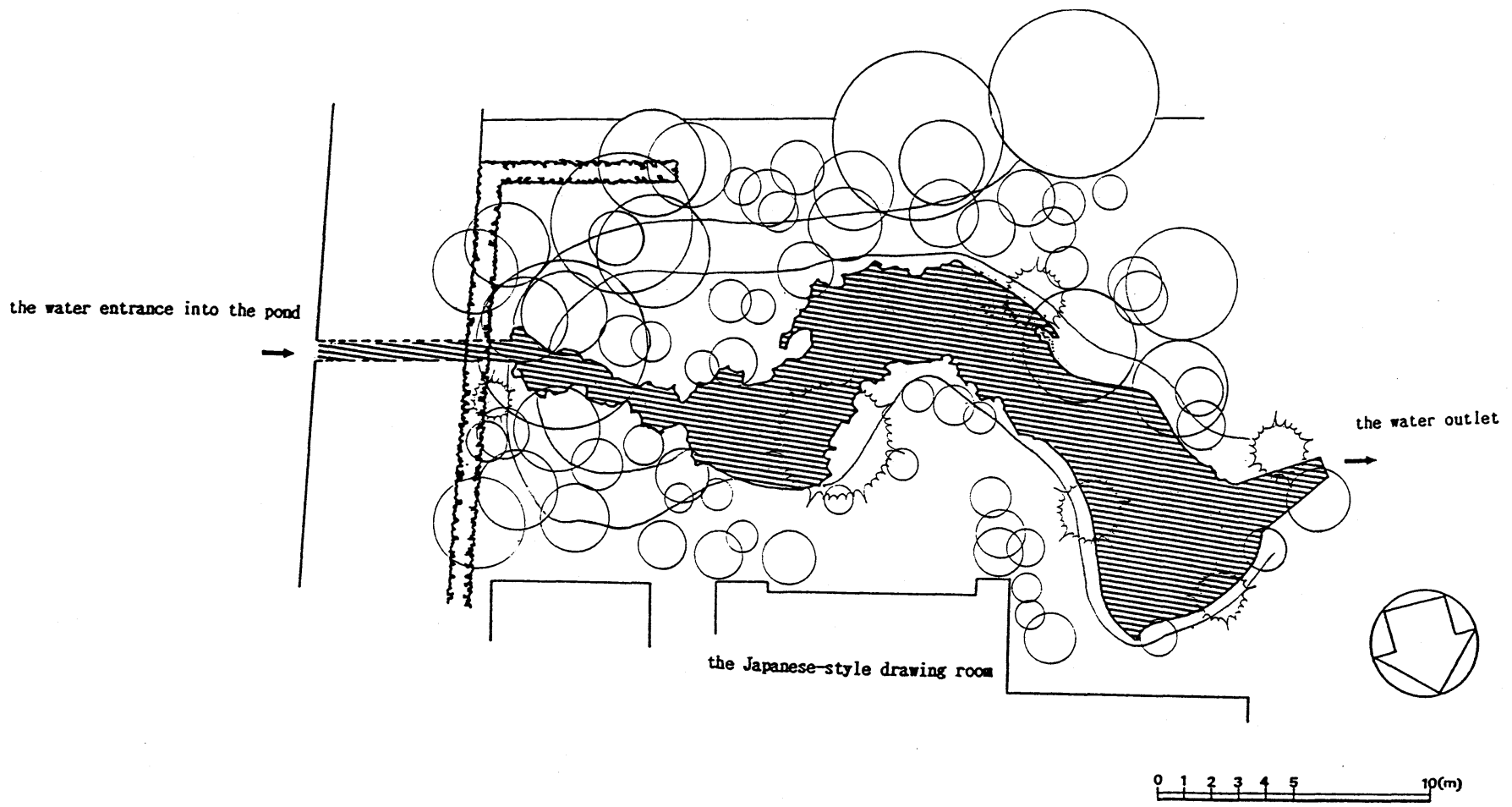

Fig.12 The garden for Syoumeiji (measured by Nagamatsu and others)

pond, takiishi is constructed with slow slope. The garden and the pond are $650 \mathrm{~m}^{2}$ and $80 \mathrm{~m}^{2}$ respectively. The garden has the giant trees such as Quercus glauca and Aphananthe aspera, which express high mountain.
13) Noda's garden (Yanagi-machi)

The garden is in the south side of the military premises, and has large pond. The space of the garden and the pond are $450 \mathrm{~m}^{2}$ and $180 \mathrm{~m}^{2}$ respectively. The water entrance of the pond is in

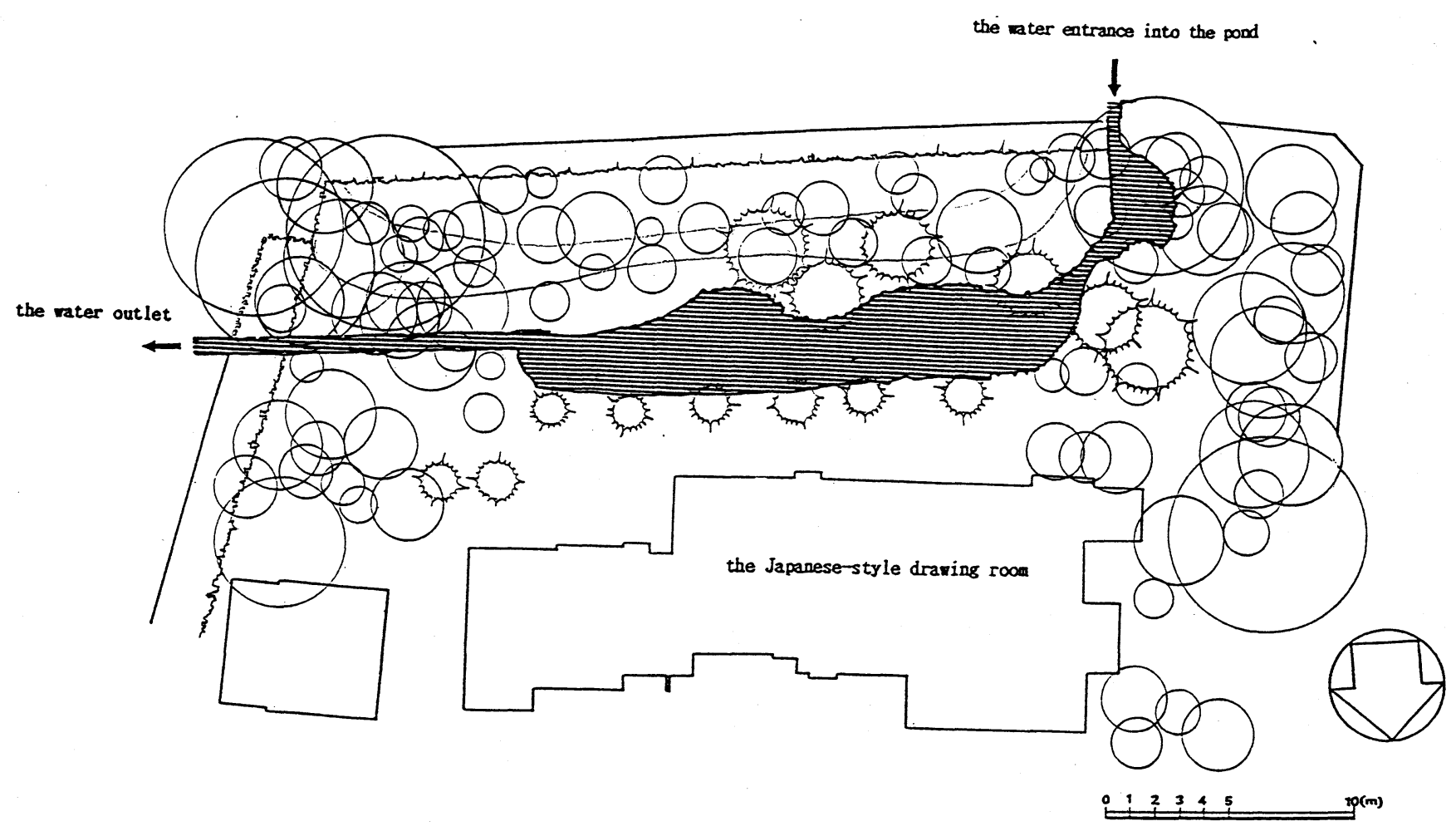

Fig.13 Takehara's garden (measured by Nagamatsu and others) 


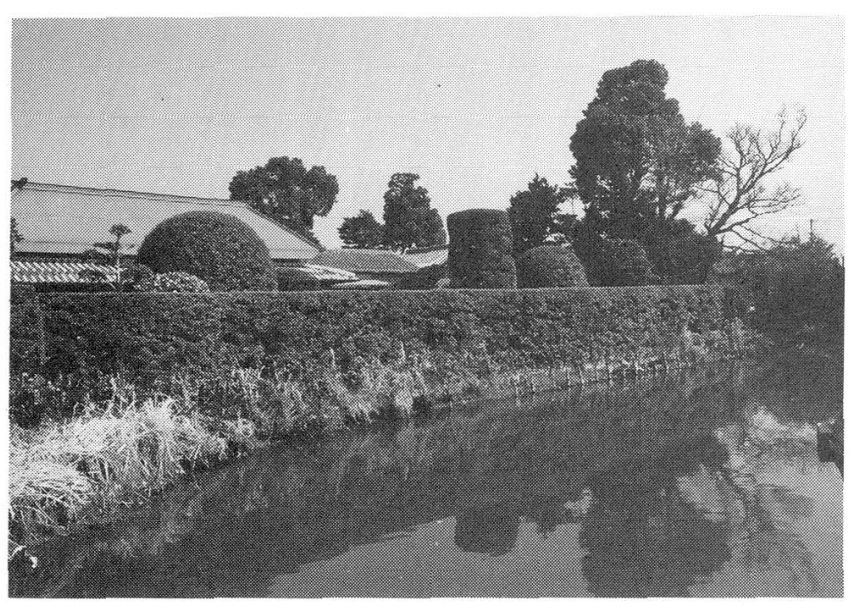

Photo 12 Takehara's garden

The garden locates in the south side of the military premises and has the pond with long and slender to the east and west.

the southeast and the flow leads to the canal in the west side (Fig.14). This is the circuit style garden having its emphasis on the large pond. The garden has Ilex rotunda and aged Podocarpus macrophylla.

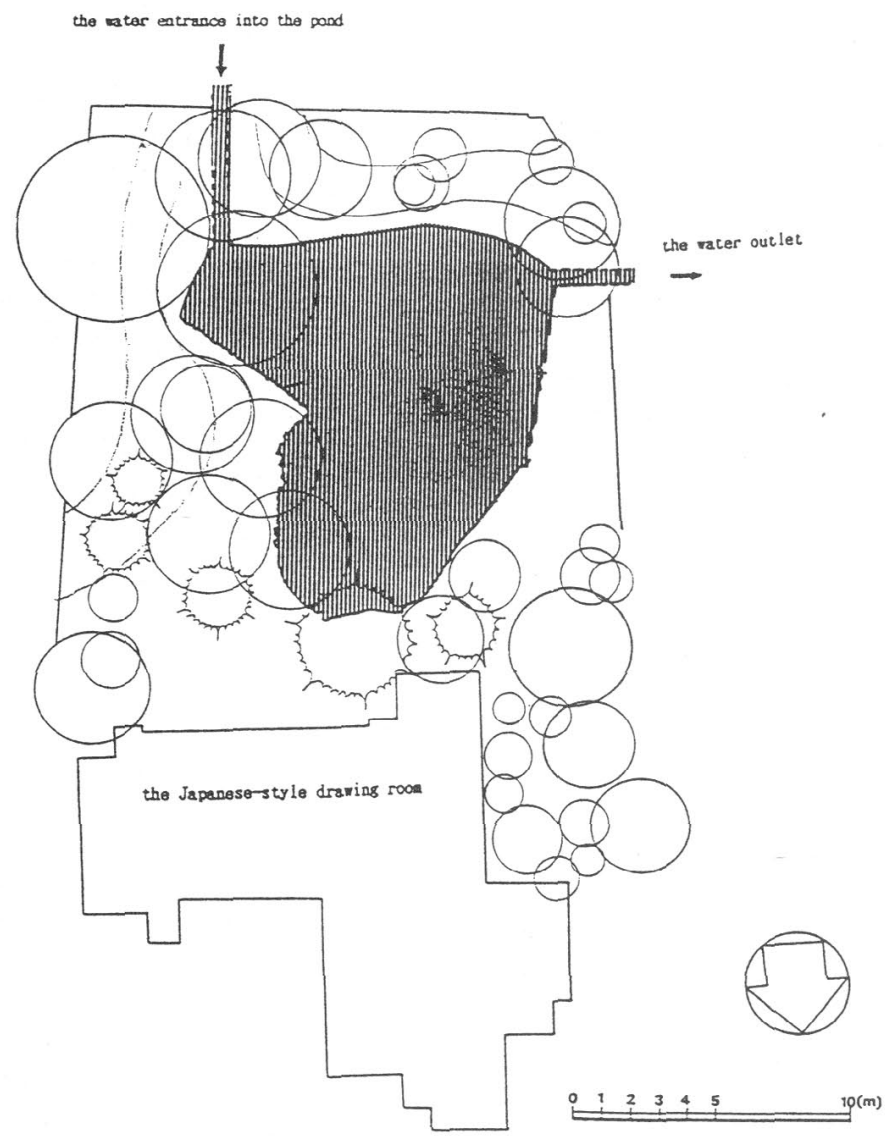

FIg. 14 Noda's garden (measured by Nagamatsu and others)

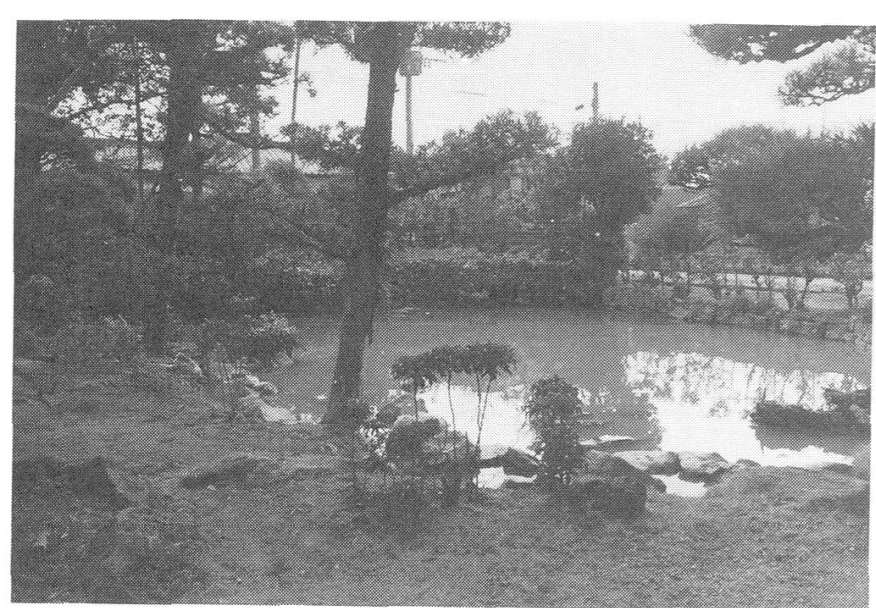

Photo 13 Noda's garden

The garden is in the south side of the military premises, and has large pond.

14) Seijirou Yamasaki's garden (Shinhoka-machi)

The garden is in the south side of the military premises. The water for the pond is from the canal in the east side. And around the water entrance of the pond, it has tateishi expressing a waterfall (Fig.15). The garden is $320 \mathrm{~m}^{2}$, and the pond, $24 \mathrm{~m}^{2}$. In the garden it has aged trees such as Cinnamomum Camphora, Ilex rotunda, and Pinus Thunbergii.

15) Tachibana's garden (Honjou-machi)

The garden having mainly a pond is in the large site which is used to be ancient Sannomaru. And it is the garden surrounded by dense trees. The garden area is $1300 \mathrm{~m}^{2}$ and the pond is $120 \mathrm{~m}^{2}$. The water rises from the east side canal and into the west side canal(Fig.16). At the back of right side in the garden, it has artificial hill expressing the high mountain. It is the elegant garden having the feature of one-view-point-style garden.

16) Aoki's garden (Ondou-machi)

The water flows into this garden from the canal which is running north and south. The garden has the long and slender pond extending to the east and west, and water flow into the west side canal (Fig.17). In the pond, it has a projecting isle and a 


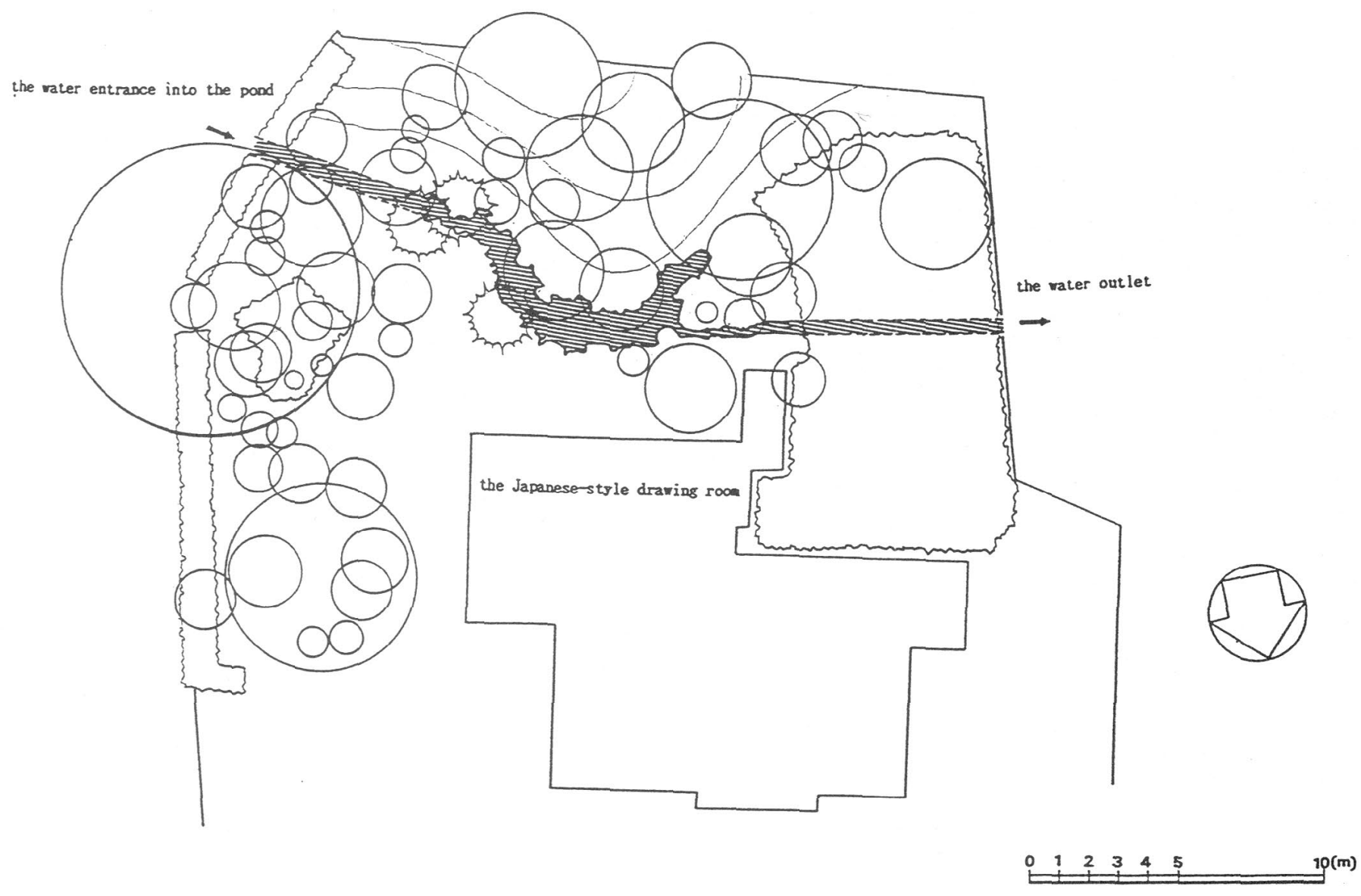

Fig.15 Seijirou Yamasaki 's garden (measured by Nagamatsu and others)

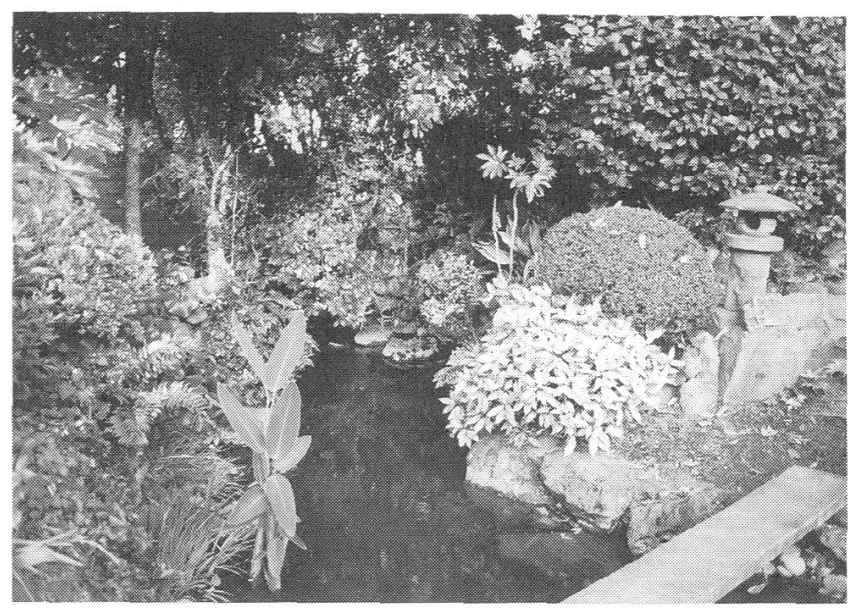

Photo 14 Seijirou Yamasaki 's garden

The garden is in the south side of the military premises. The water for the pond is from the canal in the east side.

yukimi-style stone lantern. It is a small size garden having the area of $450 \mathrm{~m}^{2}$, and the space of the pond is $56 \mathrm{~m}^{2}$. And at the back side of the garden, it has gentle high mountain, which gives us the image of deep garden.

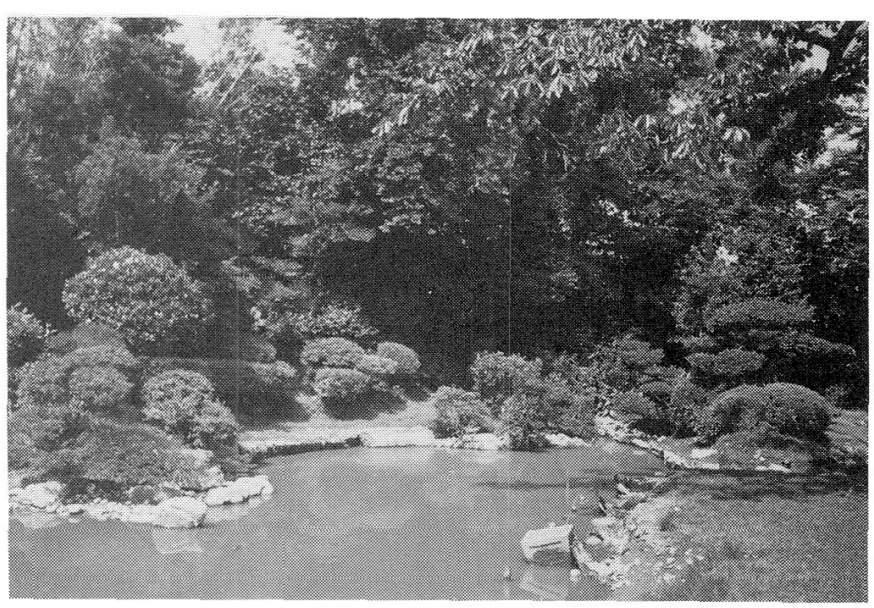

Photo 15 Tachibana's garden

The water rises from the east side canal and into the west side canal.

\section{7) Yamasaki's garden (Shinhoka-machi)}

This garden locates in the calm area of the site, and faces the south side of the drawing room. The water for the pond comes from the east side canal. At the water entrance of the pond, it has takiishi- 


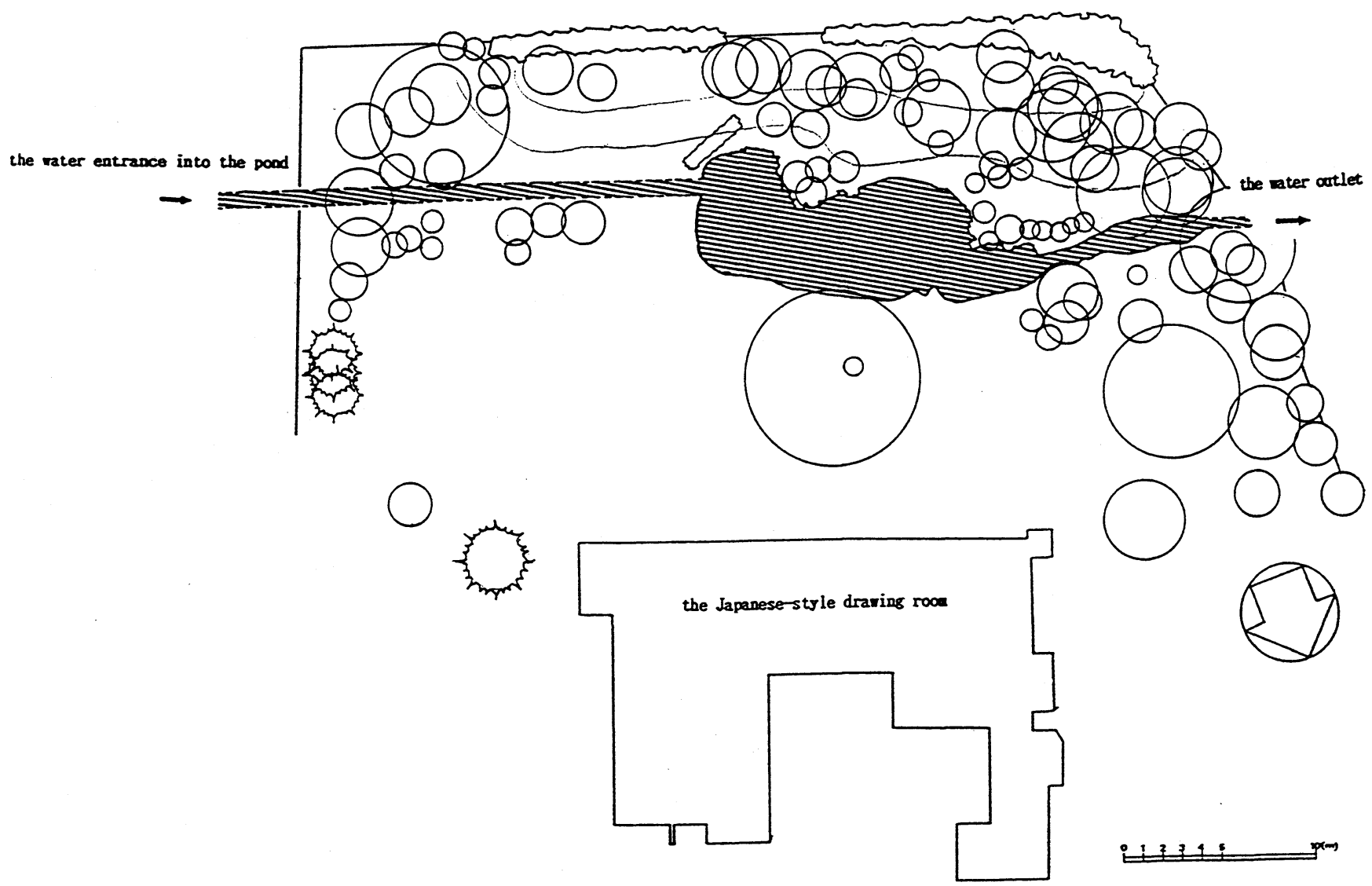

Fig.16 Tachibana's garden (measured by Nagamatsu and others)

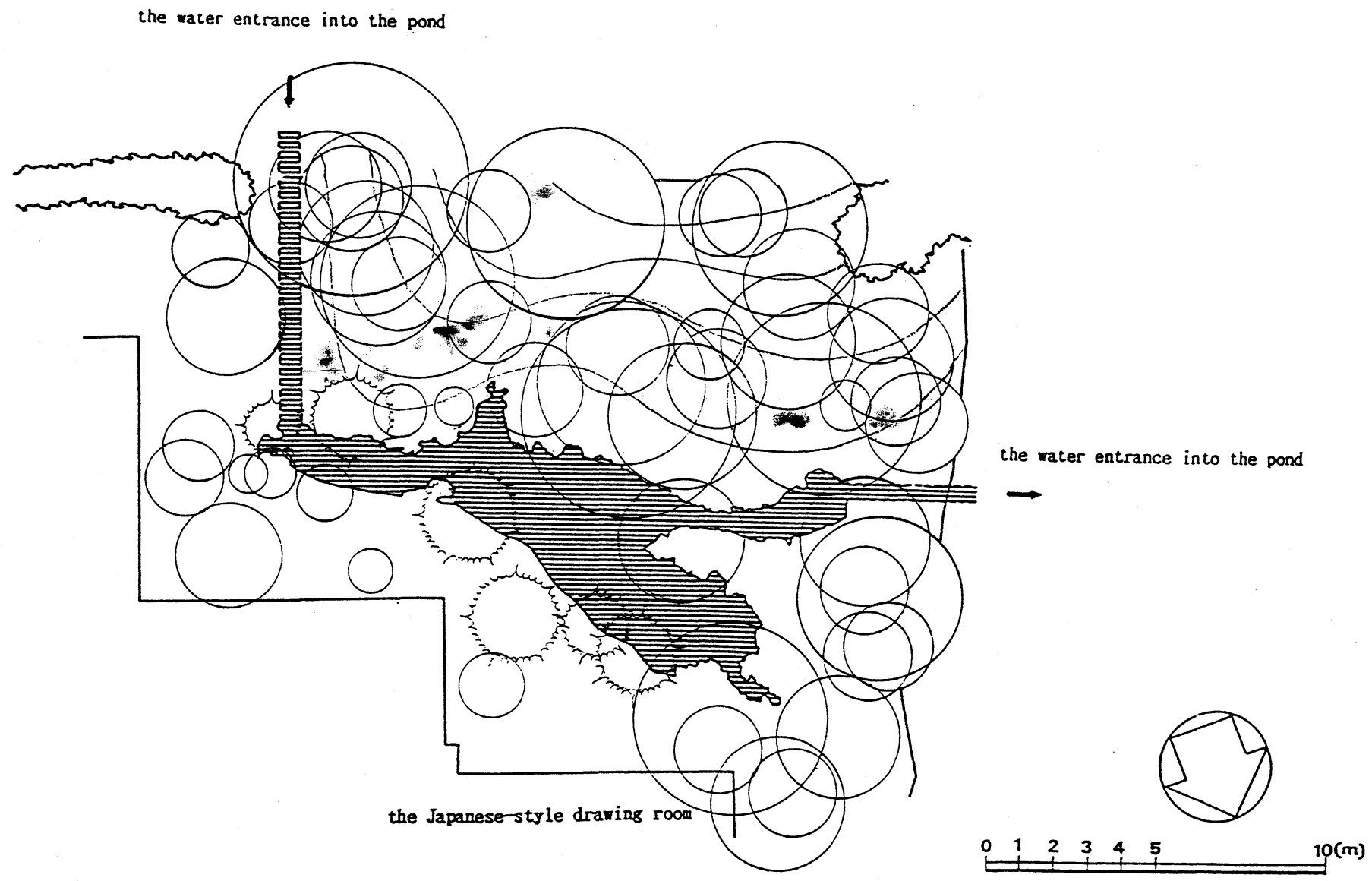

Fig.17 Aoki's garden (measured by Nagamatsu and others) 


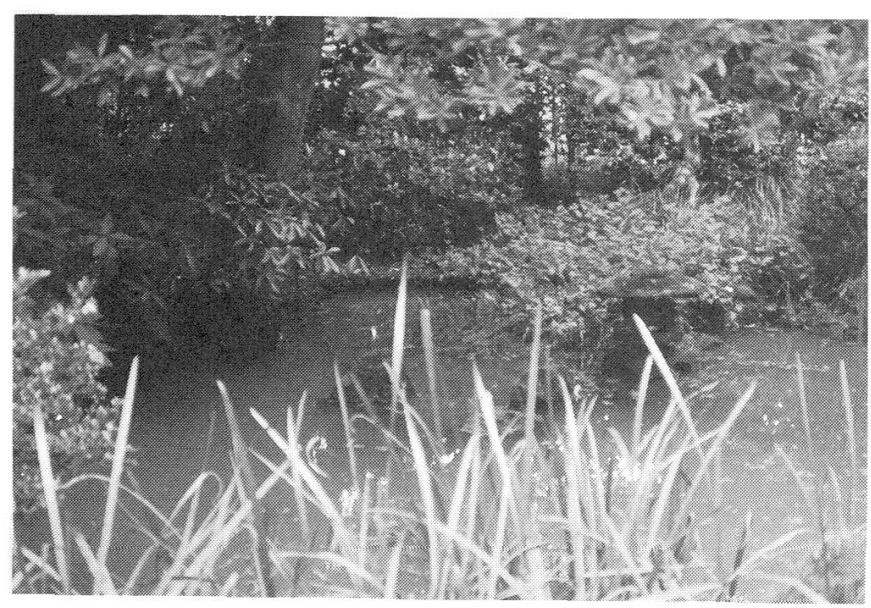

Photo 16 Aoki's garden

The water flows into this garden from the canal which is running north and south.

gumi standing for high mountain, which brings sturdiness. The water path runs east and west (Fig.18). The pond has projecting isle, and express suhama. In the center of the garden, it has a yukimi-style stone lantern as an annex landscape, which effects to have crisp landscape. The garden

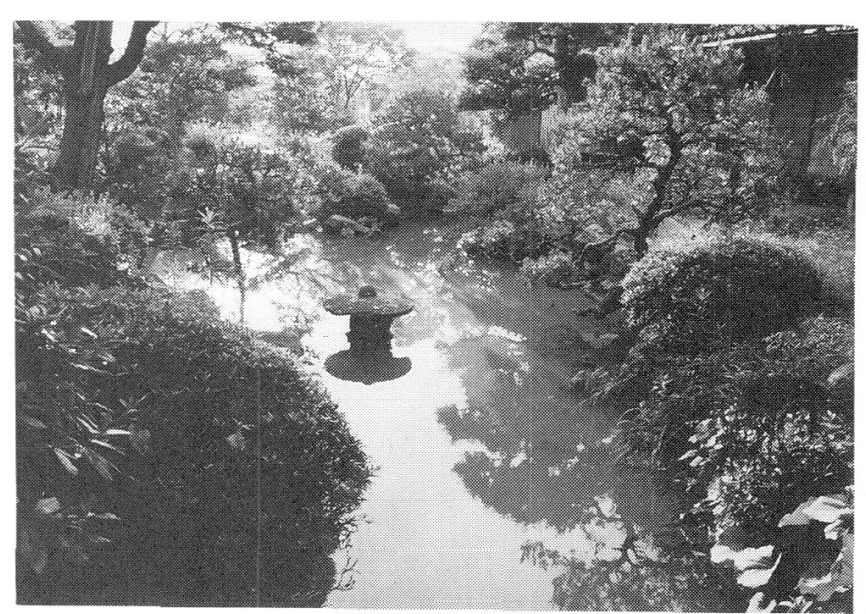

Photo 17 Yamasaki's garden

The water path runs east and west.

is $700 \mathrm{~m}^{2}$, and the pond, $60 \mathrm{~m}^{2}$. Around the pond, a few aged Pinus Thunbergii are planted.

18) Totoki's garden (Shinhoka-machi)

The water flows into the pond from east side of the site and runs to the west side by way of long and slender pond (Fig.19). The water also flows

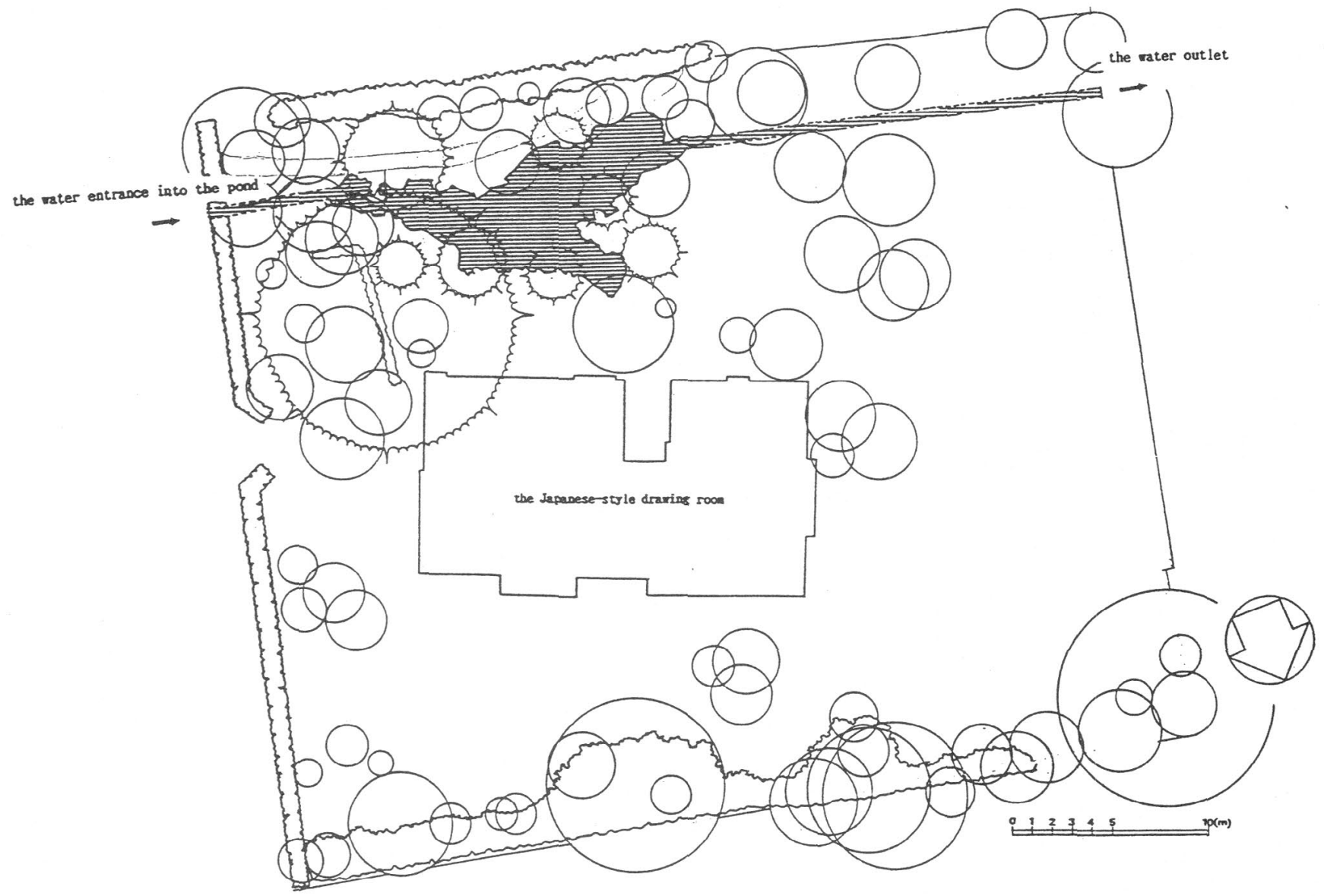

Fig.18 Yamasaki's garden (measured by Nagamatsu and others) 


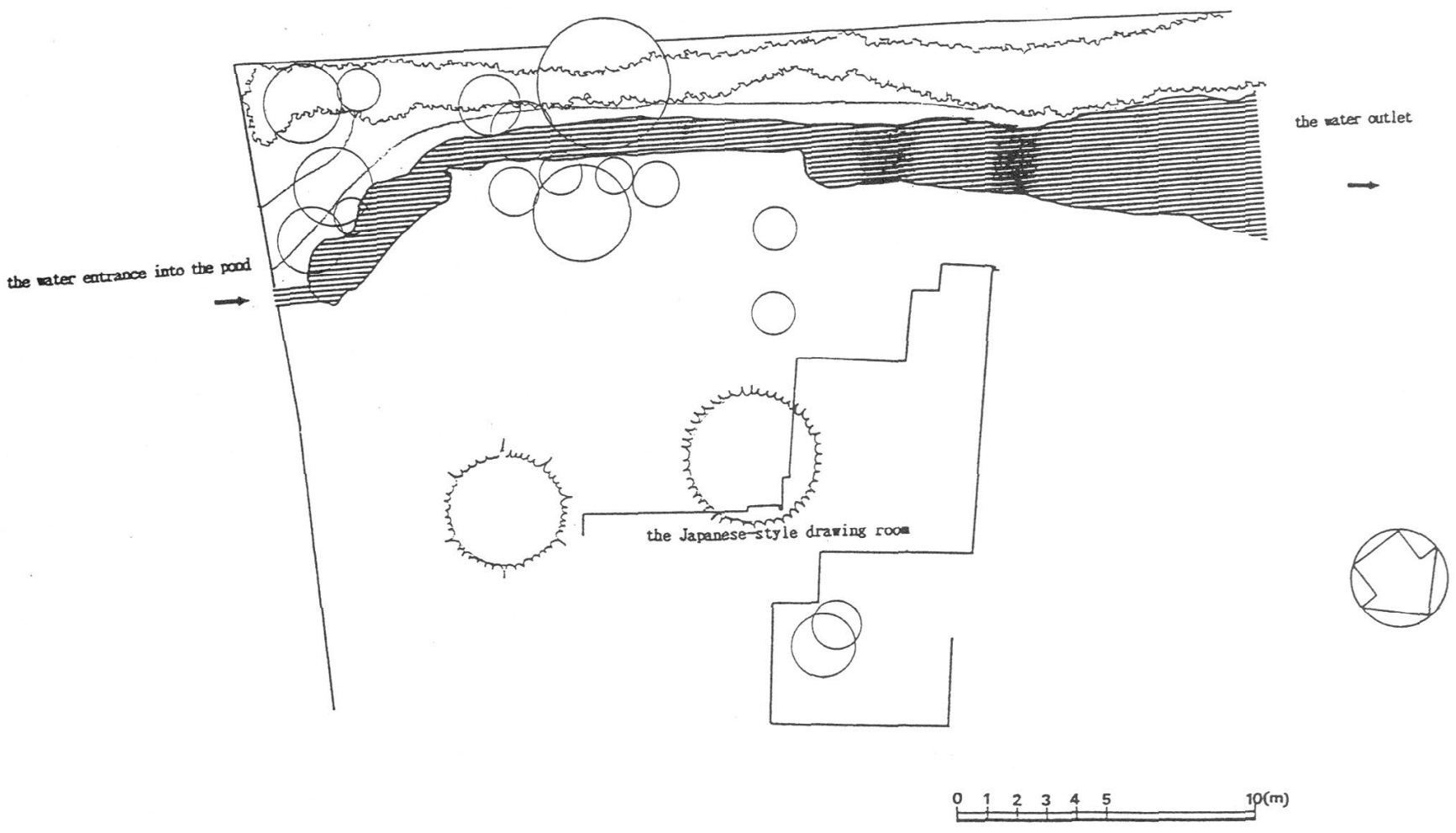

Fig.19 Totoki's garden (measured by Nagamatsu and others)

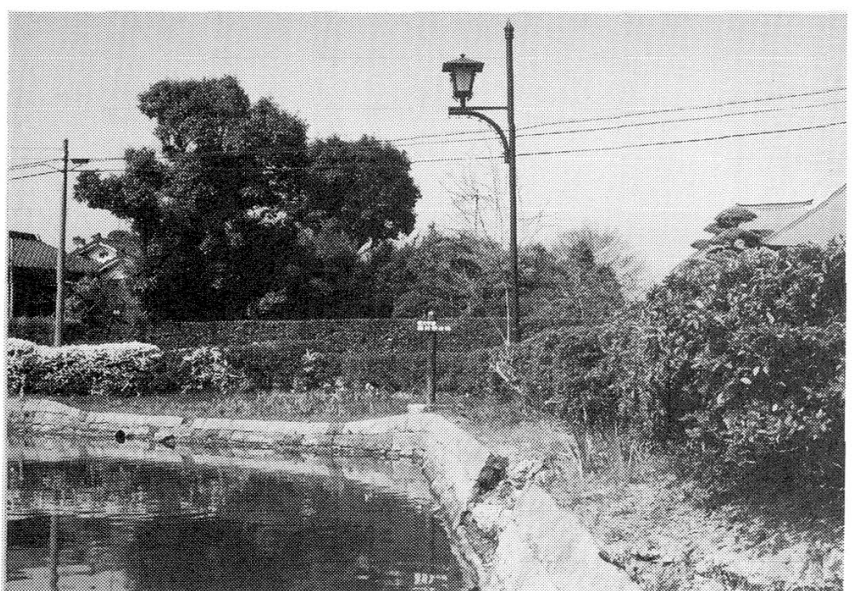

Photo 18 Totoki's garden

The water flows into the pond from east side of the site and runs to the west side by way of long and slender pond.

into the next door and has been utilized for bath water. Nowadays, only the pond are left, and the aged trees around the pond such as Quercus glauca, Podocarpus macrophylla, Pinus Thunbergii reminds us of the old days. The space of the garden and the pond are $450 \mathrm{~m}^{2}$ and $65 \mathrm{~m}^{2}$ respectively.

From the viewpoint of pond-type and planted trees, it becomes clear that the gardens in Yanagawa have the following features.

1) Pond-type and watercourse

The properties of the garden in Yanagawa concerning watercourse, pond-shape, garden space, garden type ,pond-rate (the space ratio of pond to whole garden), the way of bringing water, flowing direction, and above the water level are put into ordered gropes and shown in Table 1. These ponds can be classified into three types such as waterpooling, waterflowing(river-type), and the mixture of flowing and pooling. And each types exists in the almost same percentage.

Many of these gardens have meandering type pond, which has the effect to express deep garden even if they are actually the small size ones. The ponds occupies, in average, 13 to 14 per cent of whole garden space, and almost all of these gardens are small size ones for application having the style that the pond should be seen from the fixed position (one-view-point-style). The water into the pond is coming from the watercourse adjoining the garden, 
Table 1 Properties of the gardens in Yanagawa

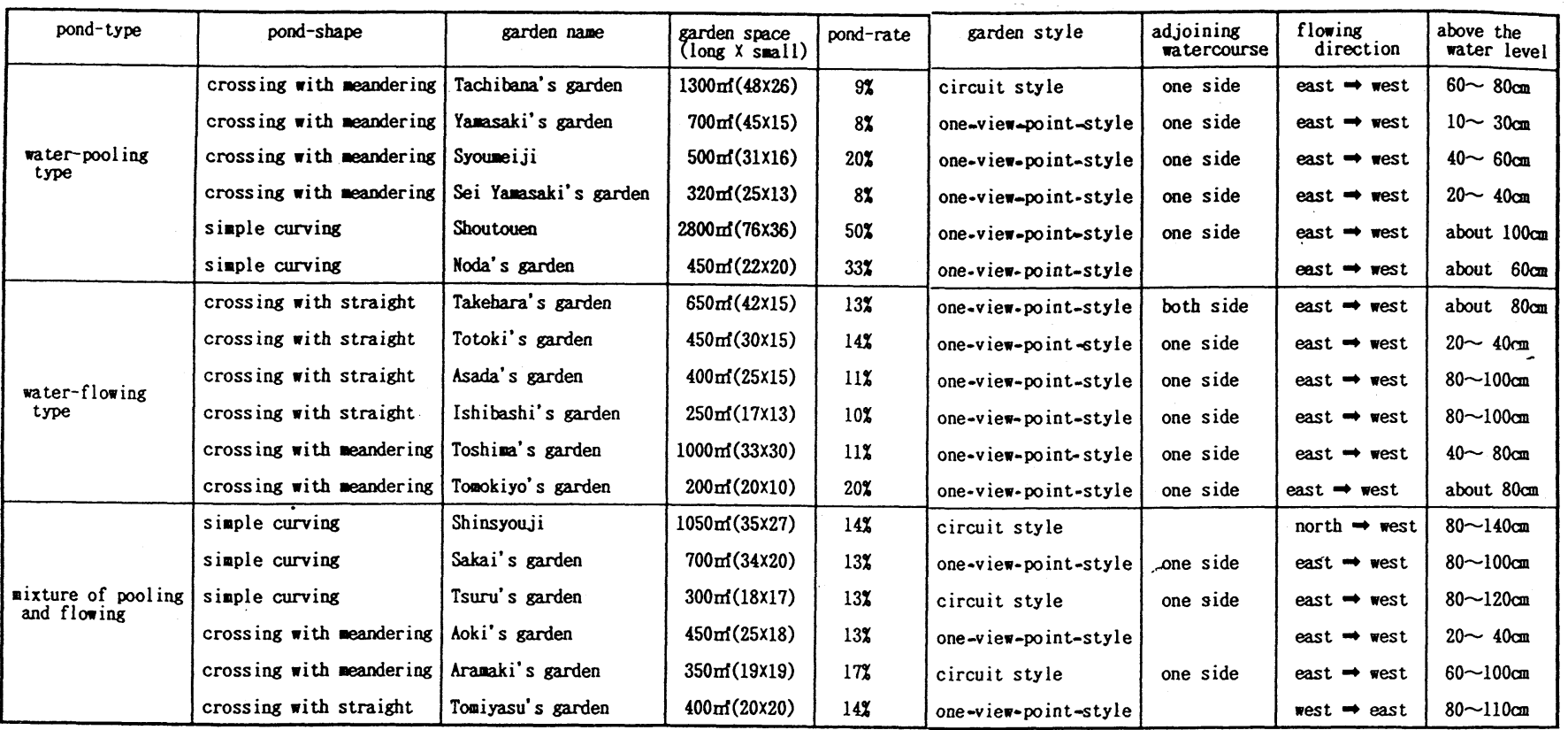

※ classification of the ponds

water-flowing type: no of little flowing (under a part of creek

flowing and pooling type(mixture of flowing and pooling type):
flowing and partially having stagnation(water comes from under ground)

Table 2 A list of trees planted in the historic gardens in Yanagawa
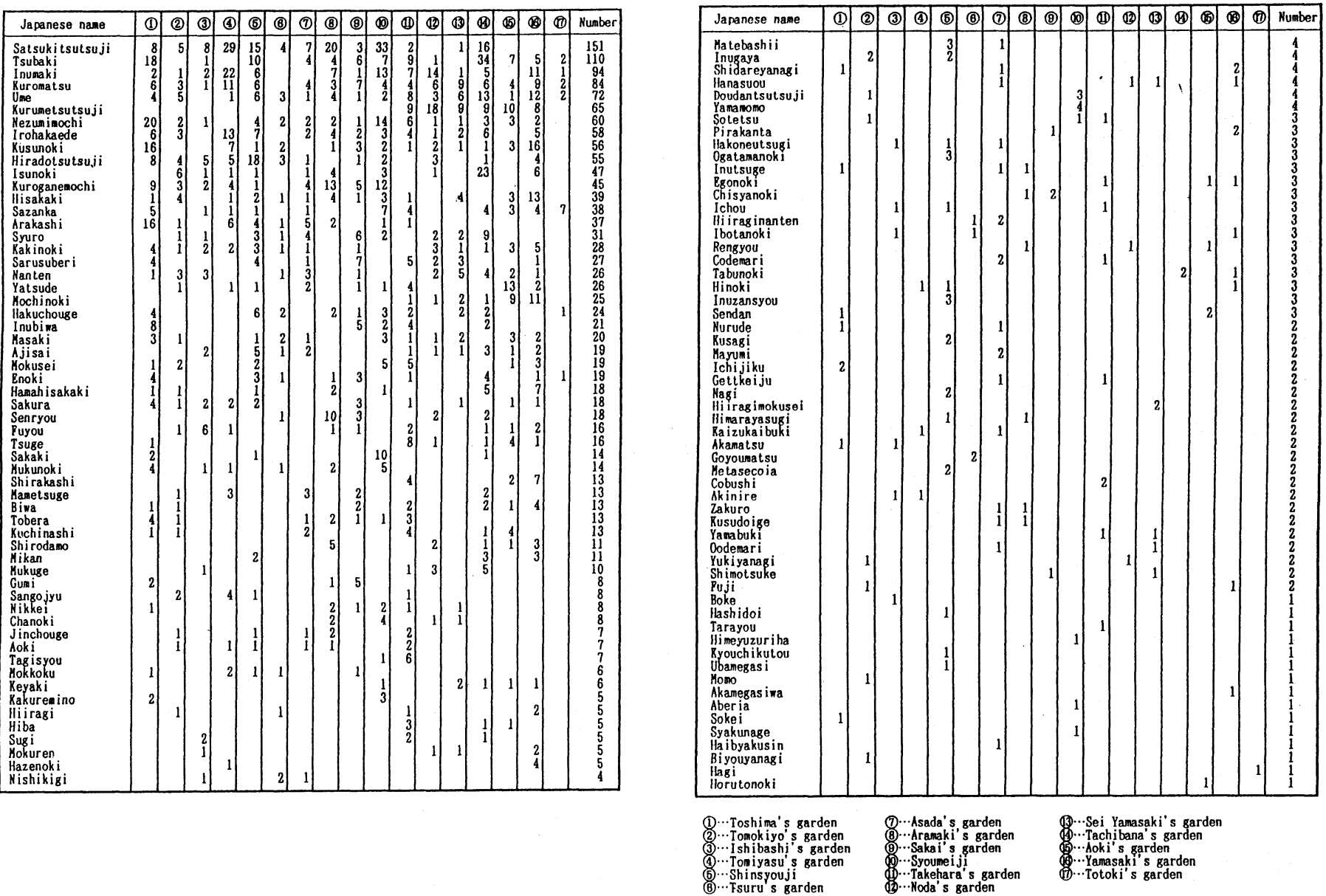
and flow east and west. The watercourse is sensitive to ebb and flow of Ariake Sea. And the water into the garden from the watercourse also has the effect of it. It means that the gardens have the "sioiri" style ponds which are changed their water level, which has the effect to make the landscape in the garden changed. These gardens in Yanagawa have only about 1 meter above the water level, and are relatively flat ones having few rugged land. The gardens are small size and flat ones, so in order to make the small gardens and ponds seen larger, they are designed by using a technique of changing pond-shape and water level of the pond.

Most of these representative gardens in Yanagawa city utilize the water path almost as they are. In Yanagawa they have been having strict restriction concerning the water utilization and using the canals to have the water for daily life. So, there are the reason why they have the idea that the water path should be public one.

2) Plants in the garden

Table 2 shows the kinds and the numbers of trees planted in each gardens. And the trees are arranged in an order based on how many they are.

Many kinds of evergreen trees are in these gardens, and as for the numbers also, they occupy more than half of whole trees planted in these gardens, which shows that the gardens in Yanagawa are mainly composed of evergreen trees.

i) The garden trees are mainly composed of evergreen shrubs such as Rhododenron indicum, $R$. obtusum, $R$. oomurasaki, and so on.

ii) Among the evergreen trees, the gardens especially have wild(native) plants, which can be seen commonly, such as Camellia japonica, Distylium racemosum, Ilex rotunda, Eurya japonica, Quercus glauca family, Ilex integra, Euonymus japonicus, Eurya emarginata, Fatsia japonica, and Gardenia jasminoides which grow in
Table 3 Classification of the garden trees in Yanagawa depended on the season

\begin{tabular}{|c|c|c|c|}
\hline Season & Japanese name & Sclentific name & Number \\
\hline$S p r i n g$ & $\begin{array}{l}\text { Satsukitsutsuji } \\
\text { Krumetsutsuji } \\
\text { Ume } \\
\text { Sakura } \\
\text { Jinchouge } \\
\text { Hokuren } \\
\text { Hanasuou } \\
\text { Rengyou } \\
\text { Codemari } \\
\text { Cobushi } \\
\text { Puji } \\
\text { Yamabuki } \\
\text { Boke } \\
\text { Momo } \\
\text { Sokei } \\
\text { Syaku }\end{array}$ & 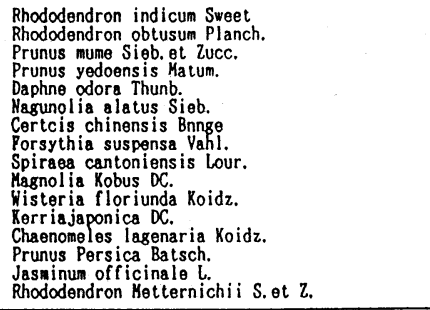 & $\begin{array}{r}151 \\
72 \\
65 \\
18 \\
7 \\
4 \\
3 \\
3 \\
3 \\
2 \\
2 \\
2 \\
2 \\
1 \\
1 \\
1 \\
1 \\
\end{array}$ \\
\hline Summer & $\begin{array}{l}\text { Sarusuberi } \\
\text { Hakuchouge } \\
\text { Ajisai } \\
\text { Enoki } \\
\text { Puyou } \\
\text { Kunchinashi } \\
\text { Bi va } \\
\text { Mikan } \\
\text { Mukuge } \\
\text { Ogatananoki } \\
\text { Zakuro } \\
\text { Shimotsuke } \\
\text { Kyouch ikutou } \\
\text { Aberia }\end{array}$ & 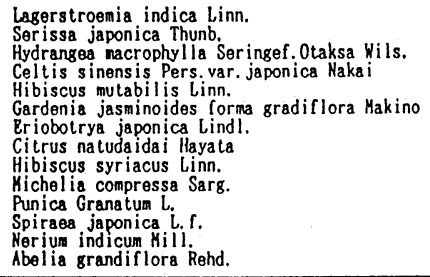 & $\begin{array}{l}27 \\
24 \\
18 \\
19 \\
16 \\
13 \\
13 \\
11 \\
10 \\
3 \\
2 \\
2 \\
1 \\
1\end{array}$ \\
\hline Autumn & $\begin{array}{l}\text { Kakinoki } \\
\text { Nanten } \\
\text { Senryou } \\
\text { Shirodamo } \\
\text { Sangojyu } \\
\text { Aoki } \\
\text { Yamamomo } \\
\text { Pirakansa } \\
\text { Hiiraginanten } \\
\text { Ichijiku }\end{array}$ & $\begin{array}{l}\text { Diospyros kaki Thunb. } \\
\text { Nandina domestica Thunb. } \\
\text { Chloranthus glabar Hakino } \\
\text { Neolitsea Sieboldi Hakai } \\
\text { Viburnum Awabuki R. Kosh } \\
\text { Aucuba japonica Thunb. } \\
\text { Myrica rubra S. ot } Z \text {. } \\
\text { Pyracantha } \\
\text { Hahonia japonica OC. } \\
\text { Picus Carica L. }\end{array}$ & $\begin{array}{r}28 \\
26 \\
18 \\
11 \\
8 \\
7 \\
4 \\
3 \\
3 \\
2\end{array}$ \\
\hline Winter & $\begin{array}{l}\text { Tsubaki } \\
\text { Sazanka } \\
\text { Hokusei } \\
\text { Hi iragi } \\
\text { Hi irasimokusei }\end{array}$ & $\begin{array}{l}\text { Camellia japonica Linn. } \\
\text { Camellia sasanqua Thunb. } \\
\text { osmanthus asiaticus Nakai } \\
\text { Osmanthus ilicifolius Houill. } \\
\text { Osmanthus portunei Carr. }\end{array}$ & $\begin{array}{r}110 \\
38 \\
19 \\
5 \\
2\end{array}$ \\
\hline
\end{tabular}

plane(open field) and low mountainous district in Kyushu.

iii) As for the deciduous trees, the gardens have especially wild ones such as Acer palmatum family and Ficus ericta. And also have many garden trees such as Diospyros kaki, Prunus mume $\underline{\underline{\text { Sieb. }}}$, and Lagerstroemia indica which are sheen in anywhere commonly.

iv) Pine family which is mainly composed of Pinus thunbergii and Podocarpus macrophylla occupy the almost all of the needle-leaf trees in these gardens.

Trees in the gardens have an effect to make these flat and plane gardens three-dimensional, and an effect to make the beauties increased.

3) Classification of the garden trees depended on the season

Main trees in the garden are classified into the four groups(four season), which is based on when its flower is in bloom, and shown in table 3 . It shows that each season can be expressed by proper use of the trees, and practically these gardens also 
have the trees taking each season into account.

\section{CONCLUSIONS}

According to our investigation of the relation between the gardens and canals in Yanagawa, it becomes clear that the water of the ponds in the gardens comes from the canals. And this water of these ponds have been utilized not only for appreciation but for daily life such as drinking water and bath-water.

These canals supplying water into the ponds and parks along the canals are important open space for the inhabitants in Yanagawa city. Also, as seen from the views such as tasteful life, the beauties of the street, and fire prevention, it seems that these have an important role.

\section{REFERENCES}

(1) Yoshihiro NAGAMATSU (1985): Relation between Water Conditions and Type of Gardens in Yanagawa City: Reprinted from Zoen-zasshi, Journal of Japanese Institute of Landscape Architects VOL48.NO.4.268-275

\section{『柳川市における掘割と} 庭園形式に関する研究』

$$
\text { 永松 義博 }
$$

南九州大学園芸学部造園学科

\section{要 旨}

柳川地方に残る武家屋敷の庭園と掘割の関係を庭園 実測によって明らかにした。庭園内の水は掘割から導 水している。取水方法や地形により、庭園を(1)池泉型 (2)流水型 (3)流水+池泉型 の3つのタイプに分けるこ とができた。庭園の多くは池泉鑑賞の形式を採り、池 水は有明海の干満の影響を受け水位が増減する潮入庭 である。庭園樹木はカシ、イスノキ、クスノキ、モチ ノキ等の柳川市周辺でみられる樹種が多く郷土色豊か なものとなっている。

\section{キーワード：1.庭園形式 2.掘割 3.回遊式庭園}

